\title{
CLT を鉄骨造の耐震要素として用いたハイブリッド構造の 接合部における支圧力の伝達に関する検討 STUDY ON COMPRESSIVE STRESS TRANSFER IN JOINTS OF STEEL FRAME HYBRID STRUCTURE WITH CLT INFILL SHEAR WALLS
}

福 本 晃 治*1, 五十田 博*2

Kouji FUKUMOTO and Hiroshi ISODA

This paper shows the following results have been achieved through the studies of the static elastic-plastic analysis and experimental results.

1. The theoretical calculation formulas for the compression area width and horizontal stiffness of CLT have been developed.

2. The formulas to calculate the coefficient of reduction of the compression area width from the theoretical calculation values were derived from the parametric study using static elastic-plastic analysis.

3. On the basis of the above findings, this paper proposes the formula to calculate the compression bearing capacity of CLT in the elastic limit and ultimate states.

Keywords : CLT (Cross laminated timber), Steel frame, Hybrid structure, Seismic wall, Compressive stress transmission, Static elastic-plastic analysis CLT（直交集成板），鉄骨架構，混合構造，而震壁，支圧力伝達，静的弾塑性解析

\section{1. はじめに}

Fig.1に筆者らが開発した CLT を鉄骨造の耐震要素として用いた ハイブリッド構造の試験体図の一例を示す。CLT と鉄骨梁はドリフ トピンによる鋼板挿入型二面せん断接合により相互に接合され、水 平力が伝達される。また、CLT と鉄骨梁フランジとの間に一定の間 隔を確保し無収縮モルタルを充填することで、CLT 木口の凹凸を均 し CLT から鉄骨梁への圧縮力の伝達を安定させるとともに、CLT の設置誤差を吸収する。また、挿入鋼板のドリフトピン孔を鉛直方 向の長孔とすることで、CLT 設置時のレベル調整を可能とすると同 時に、CLT が回転変形した際にせん断接合部に無用な鉛直力が作用 しないように配慮した。

本構造システムでは、CLT 自体に引張力を伝達する引きボルト等 の接合を設けていないため、圧縮ブレースに近い忘力状態となる。 CLT 上下の接合面には原理的に曲げモーメントが作用せず CLT は 純せん断に近い状態となり、CLTの隅角部をつなぐ斜め圧縮力が卓 越した応力状態となる。この斜め圧縮力に対して、CLT の左右に引 張材を設けることで、全体としては CLT の斜めの圧縮力とのトラ ス構造に近似した応力状態となる。

この様な、鉄骨架構に耐震要素として CLT を用いた構造システ ムについては、接合部の要素実験をもとに構造システムの実現性

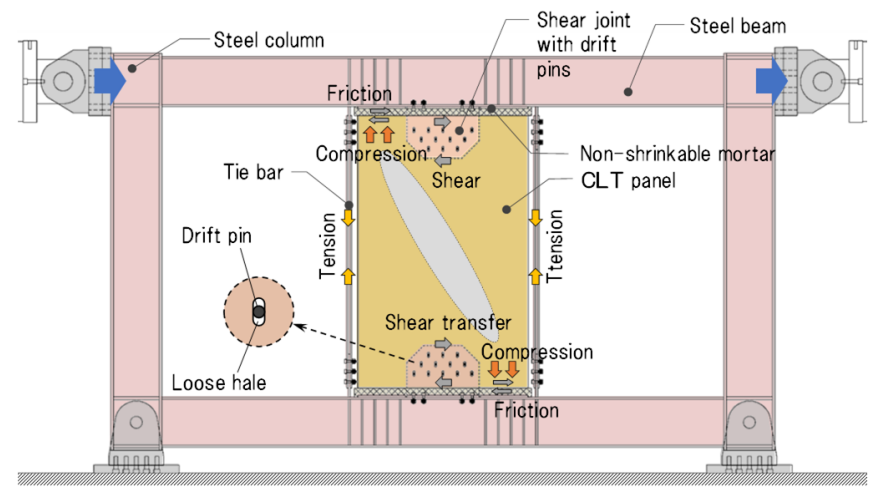

Fig. 1 Conceptual diagram (Test frame No.1)

について解析的な性能検証を実施した海外の研究 1)や、筆者による 構造設計例 2)を始めとする個別事例はあるものの、国内外を含め未 だまとまった架構実験による研究が報告されていないのが現状であ る。特に、Fig.1に示す様に CLT 自体に引きボルト等の引張接合を 持たず、CLT 対角部の支圧による回転抵抗と圧縮ストラットが主た る水平抵抗機構となるような構造の研究事例は未だ存在していない。 そこで、本研究ではこれまでに Fig.1、Fig.4に示寸1/2 スケール の架構実験を 7 体実施し、静的弾塑性解析による検討も加え、構造

"1 侏竹中工務店大阪本店設計部構造部門 副部長 · 修士（工学）／ 京都大学生存圈研究所 社会人博士課程

"2 京都大学生存圈研究所 教授·博士 (工学)

Senior Manager, Structural Engineering Section, Design Dept., Takenaka Corporation, M.Eng. / Research Institute for Sustainable Humanosphere, Kyoto Univ.

Prof., Research Institute for Sustainable Humanosphere, Kyoto Univ., Dr.Eng. 
システムの基本的な性状について参考文献 33,4)に報告した。水平外 力は、ピン支承を介した上で油圧ジャッキにより上部鉄骨梁の中心 高さに正負交番で繰り返し与え、架構試験体四隅の水平変位と鉛直 変位、CLT 上下面と鉄骨梁の相対水平変位と相対鉛直変位（Fig.2 $の \delta_{v d_{-} T L}, \delta_{v d_{-} T R}, \delta_{v d_{-} B L}, \delta_{v d_{-} B R}$ に相当) 、及び柱、梁、引張材の各部の歪 みを計測した。

この架構実験の結果、鉄骨フレームの拘束効果により、全ての試 験体において CLT が破壊に至るまでの耐力を発揮することを確認 した。破壊モードは CLT のせん断破壊と CLT 隅角部の支圧破壊に 大別される。CLT のせん断破壊は、1/75rad を超える層間変形角で 生じ $60 \%$ 程度まで耐力低下したが、その後は顕著な低下はなく大変 形時までその耐力を維持した。一方、支圧破壊が卓越する場合は、 最大耐力後の耐力低下が緩やかで変形性能に優れる結果が得られた。 本構造システムでは、原理的に CLT に生じる斜め圧縮の作用に 期待するものであり、特に隅角部における支圧特性が構造システム 全体の構造性能に影響を与えることが、上記の破壊モードによる性 状のからも想定される。更に、その支圧特性は CLT 自身の材料特性 だけでなく、CLT の上下を拘束する鉄骨梁の曲げ岡性や変形状態と も関係するものと考えられる。

そこで、本稿では実験結果と併せて、新たに静的弾塑性解析を実 施し、支圧部の挙動を解析的に分析することで、CLT 接合面の支 圧力の伝達性能について定量的に評価することを目的とする。

\section{2. 実験結果による検討}

\section{1 圧縮力に関する応力伝達モデル}

本構造システムでは上下の鉄骨梁により CLT が拘束されること により CLT の隅角部に支圧力が作用し回転抵抗を生じることで水 平剛性を発揮する。これを単純化して、上下が剛体により拘束され た CLT に水平力が作用した場合の応力モデルを Fig. 2 に示す。

幅 $L(\mathrm{~mm}) 、$ 高さ $H(\mathrm{~mm})$ 、厚さ $t(\mathrm{~mm}) 、$ CLT 強軸方向ヤング係 数 $E_{c}\left(\mathrm{~N} / \mathrm{mm}^{2}\right)$ 、支圧剛性 $k_{c}\left(\mathrm{~N} / \mathrm{mm}^{3}\right)$ の諸元を有する CLT パネルの 上下が剛体で拘束されているとき、水平力 $Q$ にり CLT パネルに $\theta_{R}$ の微小な回転が生じる。また、圧縮力により CLT 全体に $\Delta H$ の軸 変形が生じ、更に、剛体部分への接触長さ $x$ (以後、「支圧領域 幅」と称す）の範囲に支圧力、及び支圧変位が三角形分布で生じて いるものとする。また、この支圧力の合力をC とする。

この時、(1)〜 (3)式が成立する。

$$
\begin{aligned}
& \text { 支圧力： } \quad C=\frac{1}{2} k_{c} \cdot t \cdot x^{2} \tan \theta_{R} \quad \cdots \text { (1) } \\
& \text { 圧縮軸力： } C=E_{c} \cdot t \cdot L \frac{\Delta H}{H} \quad \cdots \text { (2) } \\
& \text { 支圧領域幅 : } x=\frac{L}{2}-\frac{\Delta H}{2 \tan \theta_{R}} \quad \ldots \text { (3) } \\
& \text { この(1)〜 (3)式をxについて解くと、以下が得られる。 } \\
& x=\frac{L}{2}(1-\alpha) \\
& \text { 但し、 } \quad \alpha=(1+2 \beta)-2 \sqrt{\beta(1+\beta)} \quad \cdots \text { (5) } \\
& \beta=\frac{2 E_{c}}{k_{c} \cdot H}
\end{aligned}
$$

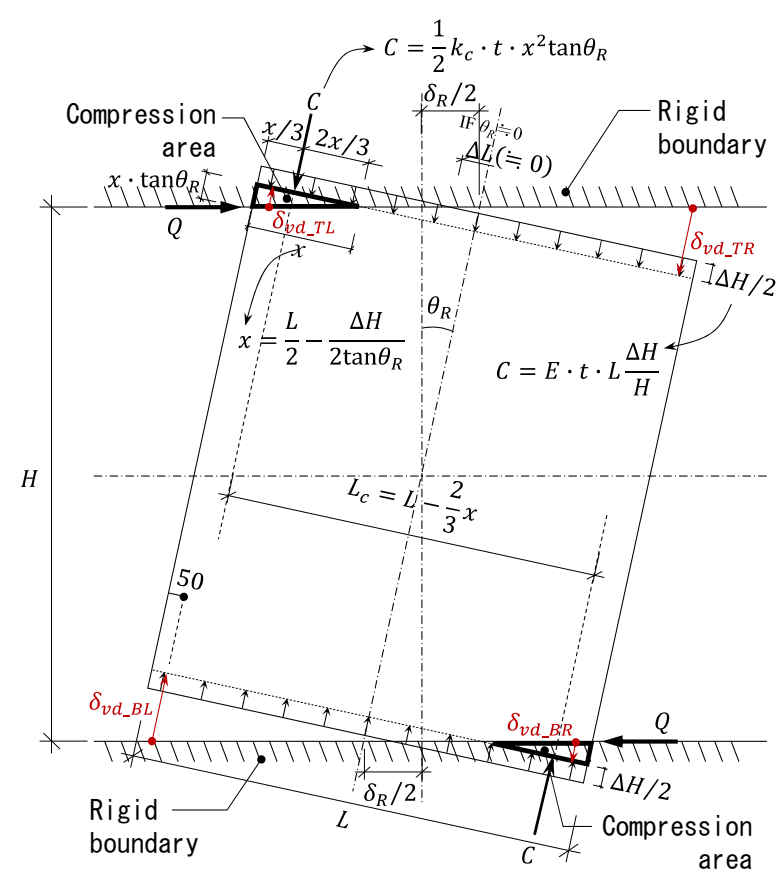

Fig. 2 Model of compressive stress transmission and momentum balance

次に、偶力モーメントのつり合いから、下式が成り立つ。

$$
Q \cdot H=C \cdot L_{c}=C \cdot\left(L-\frac{2}{3} x\right) \quad \cdots(7)
$$

(7)式に(1)式を代入し、 $\tan \theta_{R} \fallingdotseq \delta_{R} / H$ とすると、水平剛性 $K_{H}$ が得ら れる。

$$
K_{H}=\frac{Q}{\delta_{R}}=\frac{k_{c} \cdot t \cdot x^{2} \cdot\left(L-\frac{2}{3} x\right)}{2 H^{2}} \quad \cdots(8)
$$

なお、上式の解析上の妥当性については、文献 4)の（その 3 ）に て検証を実施しているので参照されたい。

本仮定は CLT を軸剛性とせん断剛性を有する線材とみなし、隅 角部の支圧状態を付加したもので、板状の挙動をする実態とはやや 異なる。しかし、CLT の任意方向のヤング係数や面内の応力度分布 は明らかでなく、ここでは文献 5)に示される標準的な解析手法も参 考にし、上記の仮定で論を進めることとする。

\section{2 支圧領域幅と支圧剛性の実験結果からの算定方法}

Fig.3 に支圧領域幅の評価について示す。(4)〜 (6)式により論理的 に得られる支圧領域幅 $x$ は、CLT の上下を無限剛性の剛体により拘 束されていると仮定したものだが、実際は CLT からの支圧力によ る曲げモーメントにより鉄骨梁に変形が生じ、上下の鉄骨梁には外 側に凸の曲率を生じることで支圧領域幅が小さくなる。

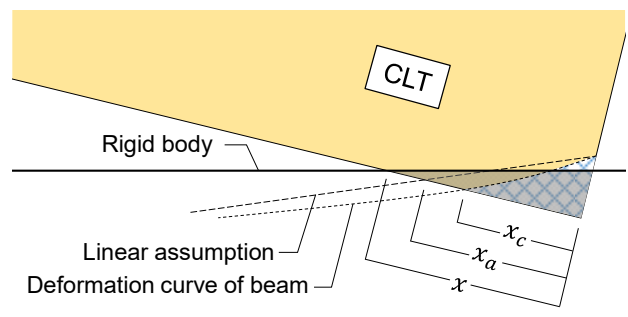

Fig. 3 Evaluation of compression area width 
そこでまず、試験体 CLT の四隅で端部から $50 \mathrm{~mm}$ 内側の位置に設 置した変位計から鉄骨梁を直線と仮定した CLT の支圧領域幅 $x_{a}$ を 算定した。そして、後述する解析検討を参考にすると、直線を仮定 した支圧領域幅 $x_{a}$ に対し鉄骨梁の曲げ変形により平均で $80 \%$ 程度 に支圧領域幅が縮小すると考えられる。そこで、実験結果における 支圧領域幅 $x_{c}$ は $x_{a}$ に対して低減係数 $(\lambda=0.8)$ を考慮して評価するこ ととした。

以上の前提で、実験結果から得られる支圧領域幅を下記のように 定義する。

CLT 上面(Top)、及び下面(Bottom)の支圧領域幅 :

$$
\begin{aligned}
& x_{a T}=(L-100) \frac{\delta_{v d_{-} T L}}{\delta_{v d_{-} T L}-\delta_{v d_{-} T R}}+50 \\
& x_{a B}=(L-100) \frac{\delta_{v d_{-} B R}}{\delta_{v d_{-} B R}-\delta_{v d_{-} B L}}+50 \\
& x_{a}=\frac{x_{a T}+x_{a B}}{2} \\
& x_{c}=\lambda \cdot x_{a}=\lambda \frac{x_{a T}+x_{a B}}{2}
\end{aligned}
$$

ただし、 $\delta_{v d_{T L}}, \delta_{v d_{-} T R}, \quad$ : 鉛直変位計測值（位置は Fig.2 によ $\delta_{v d_{-} B L}, \delta_{v d_{-} B R}$ る。圧縮側の変位が正)

$$
\lambda \text { : 低減係数 }(=0.80)
$$

支圧領域幅 $x_{c}$ が決まると、(7)式の偶力モーメントのつり合いから 支圧力 $C$ が算定できる。

$$
C=\frac{Q \cdot H}{L_{c}}=\frac{Q \cdot H}{L-\frac{2}{3} x_{c}} \quad \cdots(7)
$$

次に、 CLT 上下面の鉛直相対変位の勾配に支圧領域幅低減係数 $\lambda$ による角度の増大を考慮し接合面の回転角 $\left(\theta_{R T}, \theta_{R B}\right)$ を求める。

$$
\left.\begin{array}{l}
\theta_{R T}=\frac{1}{\lambda}\left(\frac{\delta_{v d_{-} T L}-\delta_{v d_{-} T R}}{L-100}\right) \\
\theta_{R B}=\frac{1}{\lambda}\left(\frac{\delta_{v d_{-} B R}-\delta_{v d_{-} B L}}{L-100}\right)
\end{array}\right\} \cdots \text { (11) }
$$

以上より、(1)式、(10式、(11)式より支圧剛性 $k_{c}$ が下式により算定で きる。

\begin{tabular}{|c|c|c|c|c|c|c|c|c|c|}
\hline \multirow[t]{2}{*}{$\begin{array}{l}\text { Specimen } \\
\text { No. }\end{array}$} & \multirow{2}{*}{$\begin{array}{c}\begin{array}{c}\text { Elastic } \\
\text { stiffness }\end{array} \\
K_{e} \\
(\mathrm{kN})\end{array}$} & \multirow{2}{*}{$\begin{array}{c}\begin{array}{c}\text { Maximum } \\
\text { total } \\
\text { bearing } \\
\text { force }\end{array} \\
Q_{u} \\
(\mathrm{kN}) \\
\end{array}$} & \multirow{2}{*}{\begin{tabular}{|c|}
$\begin{array}{c}\text { Maximum } \\
\text { shear } \\
\text { force } \\
\text { of } C L T\end{array}$ \\
$Q_{w u}$ \\
$(\mathrm{kN})$
\end{tabular}} & \multirow{2}{*}{ 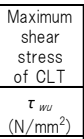 } & \multicolumn{2}{|c|}{$\begin{array}{l}\text { Comparison } \\
\text { with } \\
\text { the shear test }\end{array}$} & \multicolumn{2}{|c|}{$\begin{array}{c}\text { Story deformation } \\
\text { at the maximum shear } \\
\text { force of } C L T\end{array}$} & \multirow{2}{*}{$\begin{array}{l}\text { Failure } \\
\text { mode of } \\
\text { CLT }\end{array}$} \\
\hline & & & & & $\begin{array}{c}\tau_{\mathrm{s}} \\
\left(\mathrm{N} / \mathrm{mm}^{2}\right)\end{array}$ & $\begin{array}{l}\tau_{w v} / \tau_{s} \\
\left(\mathrm{~N} / \mathrm{mm}^{2}\right)\end{array}$ & $\begin{array}{c}\delta_{w u} \\
(\mathrm{~mm})\end{array}$ & $\begin{array}{l}\delta_{w} / H \\
(\mathrm{rad})\end{array}$ & \\
\hline No.1 & 42.1 & 885.2 & 313.9 & 2.99 & \multirow{3}{*}{3.38} & 0.88 & 35.7 & $1 / 56$ & SF \\
\hline No.2 & 50.6 & 1205.8 & 539.4 & 2.57 & & 0.76 & 47.3 & $1 / 42$ & SF \\
\hline $\begin{array}{l}\text { No.3 } \\
\end{array}$ & 65.8 & 1458.3 & 802.9 & 2.55 & & 0.75 & 30.3 & $1 / 66$ & SF \\
\hline No.4 & 22.0 & 527.5 & 267.1 & 2.54 & \multirow{4}{*}{4.21} & - & 45.9 & $1 / 44$ & $\mathrm{CF}$ \\
\hline No.5 & 31.1 & 728.5 & 455.6 & 2.89 & & 0.69 & 58.5 & $1 / 34$ & SF \\
\hline No.6 & 52.8 & 1099.0 & 487.1 & 3.09 & & 0.73 & 28.2 & $1 / 71$ & SF \\
\hline No.7 & 17.6 & 398.5 & 151.6 & 1.93 & & - & 44.6 & $1 / 45$ & $\mathrm{CF}$ \\
\hline \multicolumn{10}{|c|}{ Legend for failure mode } \\
\hline \multicolumn{10}{|c|}{ SF: Shear Failure of CLT } \\
\hline \multicolumn{10}{|c|}{$\mathrm{CF}$ : Compressive Failure of $\mathrm{CLT}$} \\
\hline
\end{tabular}

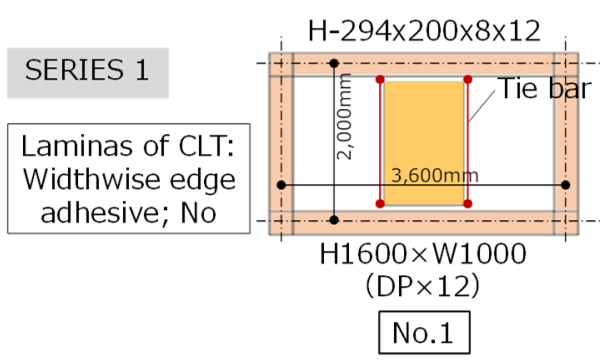

SERIES 2

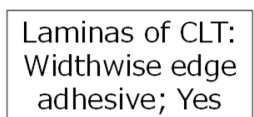

adhesive; Yes

\begin{tabular}{|c|c|c|c|c|}
\hline Series & Member & $\begin{array}{c}\text { Yield strength } \\
\sigma_{y} \\
\left(\mathrm{~N} / \mathrm{mm}^{2}\right)\end{array}$ & $\begin{array}{c}\text { Tensile strength } \\
\sigma_{u} \\
\left(\mathrm{~N} / \mathrm{mm}^{2}\right)\end{array}$ & $\begin{array}{l}\text { Breaking } \\
\text { elongation } \\
(\%)\end{array}$ \\
\hline \multirow{3}{*}{1} & $\begin{array}{c}\mathrm{H}-300 \times 300 \times 10 \times 15 \\
(\mathrm{SN} 490 \mathrm{~B})\end{array}$ & 359 & 529 & 27 \\
\hline & $\begin{array}{c}\mathrm{H}-294 \times 200 \times 8 \times 12 \\
(\mathrm{SN} 400 \mathrm{~B}))\end{array}$ & 285 & 425 & 33 \\
\hline & Drift pin $\phi 12$ & 573 & 630 & 11 \\
\hline \multirow{4}{*}{2} & $\begin{array}{c}\mathrm{H}-300 \times 300 \times 10 \times 15 \\
(\mathrm{SN} 490 \mathrm{~B})\end{array}$ & 356 & 532 & 26 \\
\hline & $\begin{array}{c}\mathrm{H}-194 \times 150 \times 6 \times 9 \\
(\mathrm{SN} 400 \mathrm{~B})\end{array}$ & 308 & 435 & 33 \\
\hline & $\begin{array}{c}\mathrm{H}-294 \times 200 \times 8 \times 12 \\
(\mathrm{SN} 400 \mathrm{~B}))\end{array}$ & 299 & 425 & 34 \\
\hline & Drift pin $\$ 12$ & 598 & 687 & 13 \\
\hline
\end{tabular}

$$
\left.\begin{array}{l}
k_{c T}=\frac{2 C}{t \cdot\left(\lambda \cdot x_{a T}\right)^{2} \tan \theta_{R T}} \\
k_{C B}=\frac{2 C}{t \cdot\left(\lambda \cdot x_{a B}\right)^{2} \tan \theta_{R B}} \\
k_{c}=\frac{k_{C T}+k_{c B}}{2}
\end{array}\right\} \cdots(12)
$$

Table 1 List of test results

Table 2 Material properties of CLT

\begin{tabular}{|c|c|c|c|c|c|}
\hline Specimen & $\begin{array}{c}\text { Compressive } \\
\text { strength } \\
\sigma_{c} \\
\left(\mathrm{~N} / \mathrm{mm}^{2}\right)\end{array}$ & $\begin{array}{c}\text { Young's } \\
\text { modulus } \\
E_{c} \\
\left(\mathrm{~N} / \mathrm{mm}^{2}\right)\end{array}$ & $\begin{array}{c}\text { Shear } \\
\text { strength } \\
\tau_{s} \\
\left(\mathrm{~N} / \mathrm{mm}^{2}\right)\end{array}$ & $\begin{array}{c}\text { Elastic shear } \\
\text { modulus } \\
G_{s} \\
\left(\mathrm{~N} / \mathrm{mm}^{2}\right)\end{array}$ & $\begin{array}{c}\text { Widthwise } \\
\text { edge } \\
\text { adhesive }\end{array}$ \\
\hline Sereis1 & 25.33 & 5601 & 3.38 & 627 & No \\
\hline Sereis2 & 22.02 & 3513 & 4.21 & 974 & Yes \\
\hline
\end{tabular}

Table 3 Material properties of steel 


\section{3 試験体一覧}

Fig.4 に本検討で対象とした試験体一覧を示す。試験体は $1 / 2$ ス ケールとし、CLT 配置枚数をパラメータとした試験体 No.1〜No.3 からなる第 1 シリーズと、試験体のアスペクト比及び鉄骨の梁断面 を変化させた試験体 No.4〜No.7 からなる第 2 シリーズがある。

Table1 に実験結果一覧を示す。破壊モードは試験体 No.4、No.7 では CLT のせん断破壊が生じず支圧破壊が卓越し、それ以外の試 験体では支圧破壊の進行が認められたものの、最終的にせん断破壊 が生じて最大耐力に達した。後の Fig.14でも示されるように、CLT のせん断破壊が発生する場合、層間変形角が $1 / 71 \mathrm{rad}$ 以上と比較的 大変形で生じた。支圧破壊が卓越する場合は、最大耐力後の耐力低 下が緩やかで変形性能に優れる結果となった。

なお、Table2 にCLT の材料試験結果、Table3 に鋼材の材料試験 結果を示す。CLT は、幅はぎ接着のある第 2 シリーズの方が強軸方 向の圧縮ヤング係数と圧縮強度が低く、せん断弾性係数とせん断強 度が高くなる結果であった。

\section{4 支圧領域幅と支圧剛性の検討結果}

Fig.5 に(9)式、(10式により実験結果から算定した支圧領域幅 $x_{c}$ と 層間変形 $\delta$ 、及び12式により算定した支圧剛性 $k_{c}$ と層間変形 $\delta$ との 関係を示す。なお、試験体 No. 2 と No3 は変位計の計測結果が安 定していた左側 CLT を代表して示した。

まず、後に Fig.14に示す荷重変形関係において CLT の剛性低下 が始まる層間変形角は 1/200 rad 1/100 rad の付近に存在してお り、この区間に弾性限界が存在していると推察される。

そこで、Fig.5において、第 1 シリーズの試験体 No.1〜No.3に ついて見ると、層間変形角が 1/200rad あたりまでは支圧領域幅が 小さく支圧剛性が高い值を示すとともに CLT 上下面のばらつきも 大きいが、層間変形が 1/150rad を超えた付近で CLT 上下面の支 圧領域幅の值が同等となり安定した結果となる。

計測結果が安定した層間変形角 1/150rad〜1/100rad の区間で見 ると、支圧剛性の平均值の極大点（グラフ上の赤点）がある。な お、試験体 No.3 については、最初の点（ $\delta=15.5 \mathrm{~mm}$ の点）にお いても上下面の計測結果にやや乘離があるため、層間変形角 1/100rad 付近の極大点も示した。

1/100rad 以降は、支圧領域幅は上下面でほぼ一定の值となる が、支圧剛性は加力サイクル毎に段階的に低下し、更に層間変形の 増大ともに徐々に低下した。

また、第 2 シリーズの試験体 No.4 No.7 は第 1 シリーズより安 定した計測結果が得られた。初期段階では第 1 シリーズと同様に 支圧領域幅は小さく支圧剛性が高い值を示したが、早期に CLT の 上下面の值が同等となり安定した結果となった。

第 2 シリーズでも、Fig. 14 に示寸荷重変形関係において弾性限 界が存在すると考えられる層間变形角が 1/200 rad 1/100rad の間 で、支圧剛性の平均值の極大点（グラフ上の赤点）がある。

1/100rad 以降は、第 1 シリーズと同様に支圧領域幅は微増する もののほぼ一定の值を維持するが、支圧剛性は加力サイクル毎に段 階的に低下し、更に層間変形の増大ともに低下した。以上のよう に、第 1 シリーズ、第 2 シリーズとも弾性限界が存在すると考え られる層間変形角 1/200～1/100rad の間に、グラフ上の点で示し
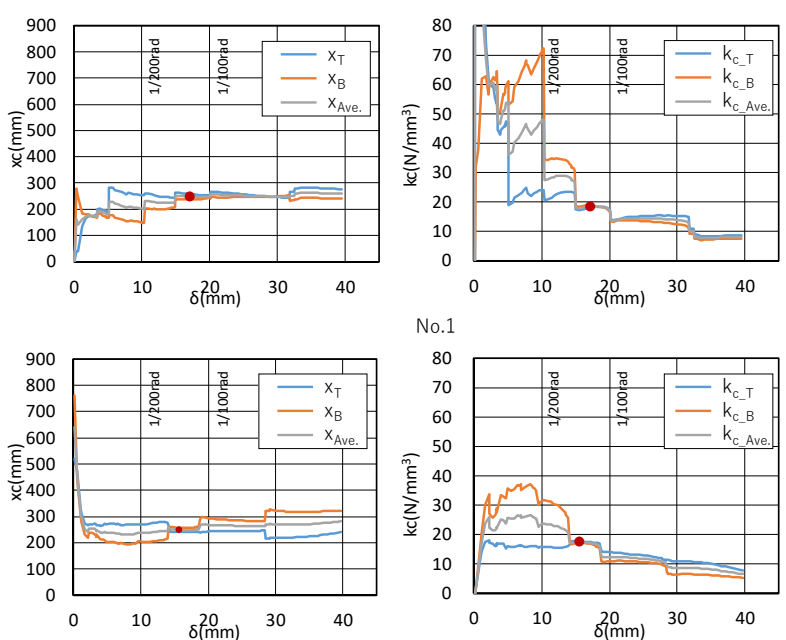

No.1
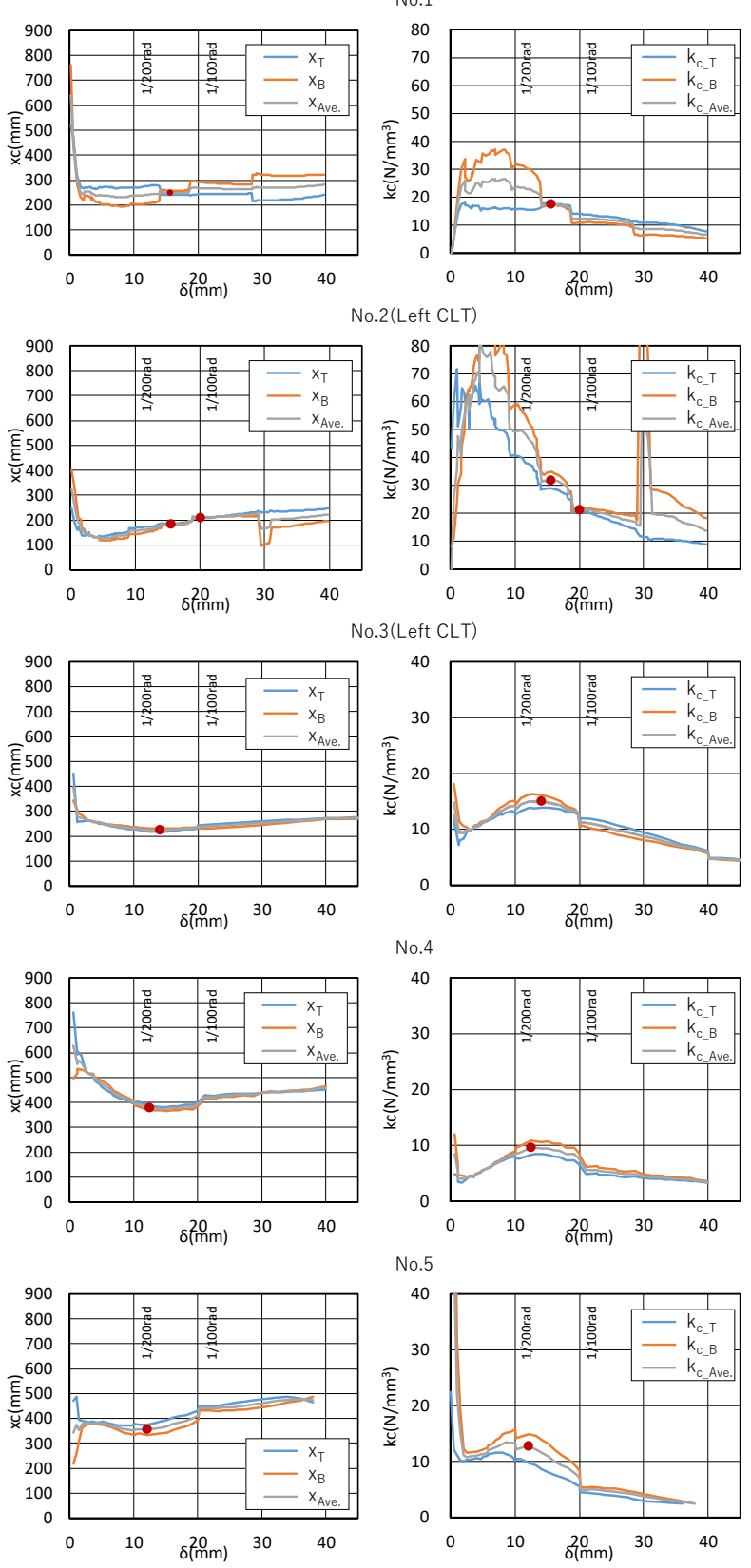

No.6
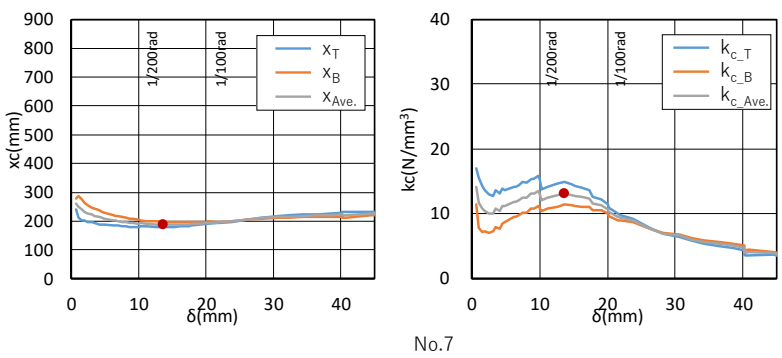

Fig. 5 Relations between compression area width $\left(x_{c}\right)$ or compression stiffness $\left(k_{c}\right)$ and story deformation $(\delta)$ 
た支圧剛性の極大点が存在している。

以上のことから、各試験体とも 1/200 $\mathrm{rad} \sim 1 / 100 \mathrm{rad}$ の間で支圧 剛性が極大となる時点で、弾性限界時の支圧領域幅 $x_{c}$ と支圧剛性 $k_{c}$ を定めて検討を実施する。

まず、Fig.6 に上記により求めた弾性限界時の支圧剛性の CLT 上 下面の平均值 $k_{c}$ と、CLT の圧縮ヤング係数 $E_{c}$ との関係を示す。なお、 試験体 No.3 については他の試験体との整合も勘案し、弾性限界と して Fig.5 に示したグラフの第 2 点目の值を採用した。Fig.6 によ ると、支圧剛性はヤング係数と比例関係が認められ、下式の関係が 得られた。

$$
\begin{aligned}
& k_{c}=\frac{E_{c}}{290}\left(\mathrm{~N} / \mathrm{mm}^{3}\right) \\
& \left(\text { ただし、 } E_{c} \text { の単位は }\left(\mathrm{N} / \mathrm{mm}^{2}\right)\right. \text { とする。 }
\end{aligned}
$$

(13)式は CLT の圧縮ヤング係数 $E_{c}$ を分子にして単位が（力／長さ の 3 乗）となるが、分母が長さの単位を持ち支圧に有効な CLT の 範囲が支圧面より $290 \mathrm{~mm}$ の範囲になるという見方もできる。

次に、Fig.7 に(10式により算定した弾性限界時、終局時の $x_{c}$ と CLT 幅Lとの関係を示寸。グラフでは弾性限界時に合わせて、層間

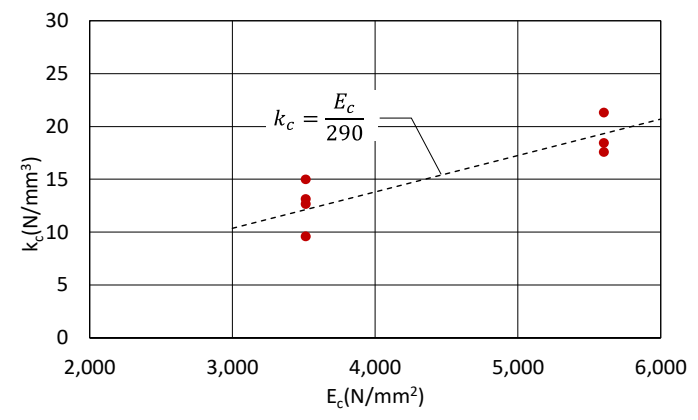

Fig. 6 Relations between compression stiffness $\left(k_{c}\right)$ and Young's modulus $\left(E_{c}\right)$

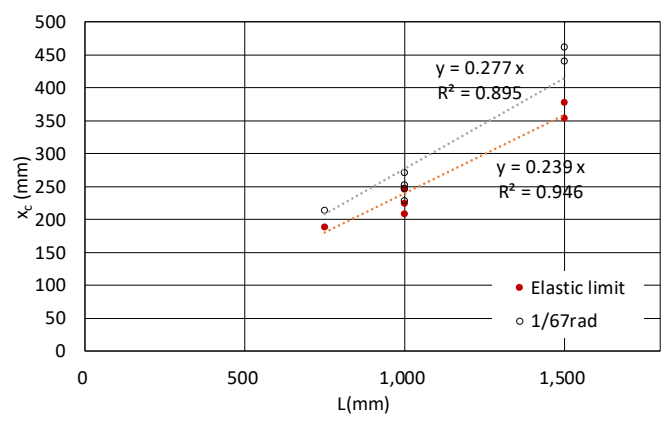

Fig. 7 Relations between compression area width $\left(x_{c}\right)$ and CLT width $(L)$

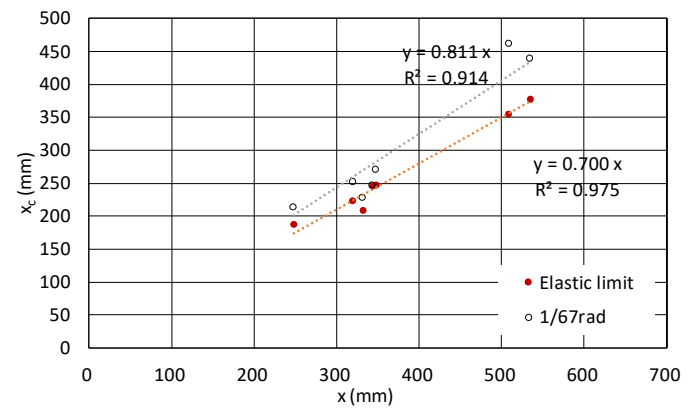

Fig. 8 Relations between experimental results $\left(x_{c}\right)$ and calculation results $(x)$ in terms of compression area width
変形角が $1 / 67 \mathrm{rad} （ \delta=30 \mathrm{~mm} ）$ 時点での結果も併せて示す。 $x_{c}$ は $L$ にほぼ比例関係にあり、弾性限界時においては CLT 幅の $24 \%$ 、層 間変形角 $1 / 67 \mathrm{rad}$ 時では $28 \%$ となり支圧破壊の進行により支圧領 域幅がやや拡大寸る結果となった。なお、文献 5)において、支圧領 域幅を応力中心間距離の $1 / 4$ として算定する耐力式となっている が、本検討結果からも概初妥当な評価と考えられる。

また、Fig.8 に(4)式〜 (6)式による支圧領域幅の理論值 $x$ と $x_{c}$ の比 較を示す。実験值の理論值に対する比率は、弾性限界時においては $70 \% 、 1 / 67 \mathrm{rad}$ 時は $81 \%$ となり、理論值よりやや小さい数值になる ものの実験結果と理論值はほぼ線形関係にある。

\section{5 接合面の鉛直変位分布と弾性限界時支圧変形、終局時支圧変形}

CLT 支圧部の支圧応力度と支圧変形の関係を完全弾塑性型の挙 動だと仮定すると、CLT の圧縮強度 $\sigma_{c}$ と、支圧剛性 $k_{c}$ との関係から、 CLT 支圧部の縁端部で圧縮強度に達したときの「弾性限界時支圧変 形 $\delta_{c e} 」$ を定義することができる。

$$
\delta_{c e}=\frac{\sigma_{c}}{k_{c}}
$$

また、支圧変形 $\delta_{c}$ は下式により縁端部の圧縮歪みに換算できる。

$$
\varepsilon_{c}=\frac{k_{c}}{E_{c}} \cdot \delta_{c} \quad \cdots(15)
$$

支圧破壊が破壊モードとなる場合の最大耐力時の縁端部の支圧変 形を「終局時支圧変形 $\left.\delta_{c u}\right\rfloor$ とすると、下式より最大耐力時の縁端部 における終局圧縮歪みが算定できる。

$$
\varepsilon_{c u}=\frac{k_{c}}{E_{c}} \cdot \delta_{c u} \quad \text { (...16) }
$$
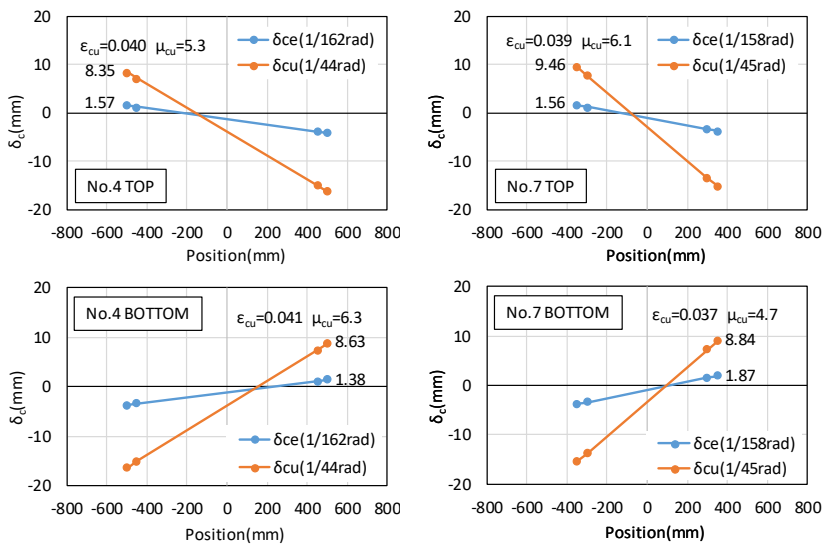

Fig. 9 Distribution of vertical relative displacements in top and bottom connection boundaries, specimens No. 4 and No. 7
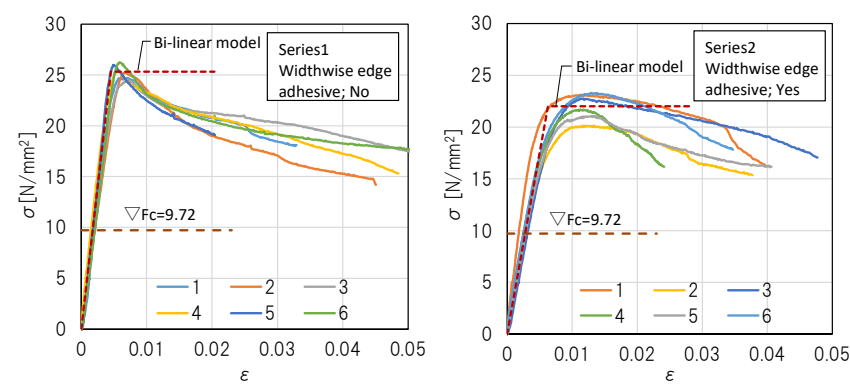

Fig. 10 Results of CLT compression tests 
更に、終局時支圧変形の弾性限界時支圧変形に対する倍率を「終 局時支圧塑性率 $\left.\mu_{c u}\right\rfloor$ として、下式により定義する。

$$
\mu_{c u}=\frac{\delta_{c u}}{\delta_{c e}} \quad \cdots(17)
$$

Fig.9 にせん断破壊を生じなかった試験体 No.4 と No.7について、 縁端部の支圧変形が $\delta_{c e}$ (Fig.2 に示した赤点時の変形)、 $\delta_{c u}$ に達し たときの支圧部接合面の鉛直変位分布を示す。支圧部縁端部の最大 耐力時の圧縮歪みはいずれも $\varepsilon_{c u}=0.04$ 前後となり、終局時支圧塑性 率は $\mu_{c u}=4.7 \sim 6.3$ となった。Fig.10 に示す圧縮強度試験結果による と、この歪み領域では圧縮強度が最大值の 7 割程度に低下している ことになるが、架構実験においては最大耐力時までは耐力を維持し ており、文献 6)等にも示されるように部分圧縮の影響により最大強 度に達した後の強度低下が材料試験結果より緩やかなものになると 推察される。

\section{3. 解析的検討}

ここでは、2.において得られた実験結果をもとに、静的弾塑性解 析による架構実験の再現性を検証し、その上で、CLT 支圧部の挙動 について解析結果による詳細な検討を行った。

\section{1 解析モデル}

Fig.11に解析モデルを示す。CLT パネルは線材弾性要素とし、上 下端に CLT 幅と同じ長さを有する剛体を設けた。また、本構造シス テムにおける CLT は原理的に曲げ変形を生じないため、断面 2 次 モーメントIを極大とした。

鉄骨梁要素と CLT 剛体要素との境界には支圧挙動を模擬したバ

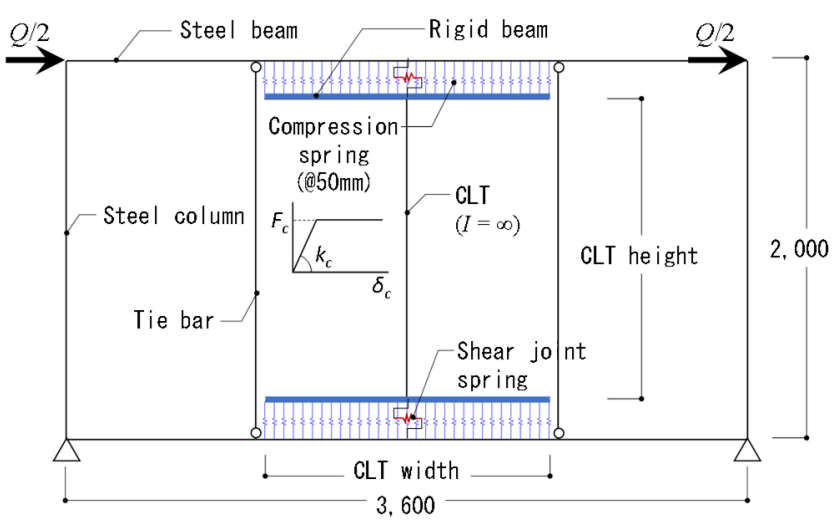

Fig. 11 Analysis model

Table 4 Properties of analysis model

\begin{tabular}{|c|c|c|c|c|c|c|c|}
\hline \multirow{3}{*}{$\begin{array}{c}\text { Test } \\
\text { frame } \\
\text { No. }\end{array}$} & \multirow{2}{*}{\multicolumn{2}{|c|}{$\begin{array}{c}\text { Steel frame } \\
\text { Steel } \\
\text { yeild strength }\end{array}$}} & \multicolumn{2}{|c|}{ CLT } & \multicolumn{3}{|c|}{ CLT joint } \\
\hline & & & \multirow{2}{*}{$\begin{array}{c}\begin{array}{c}\text { Young's } \\
\text { modulus }\end{array} \\
\begin{array}{c}E_{c} \\
\left(\mathrm{~N} / \mathrm{mm}^{2}\right)\end{array}\end{array}$} & \multirow{2}{*}{$\begin{array}{c}\begin{array}{c}\text { Elastic } \\
\text { shear } \\
\text { modulus }\end{array} \\
\begin{array}{c}G \\
\left(\mathrm{~N} / \mathrm{mm}^{2}\right)\end{array}\end{array}$} & \multirow{2}{*}{$\begin{array}{c}\begin{array}{c}\text { Compression } \\
\text { sttifness }\end{array} \\
k_{c} \\
\left(\mathrm{~N} / \mathrm{mm}^{3}\right)\end{array}$} & \multirow{2}{*}{$\begin{array}{c}\begin{array}{c}\text { Compression } \\
\text { strength }\end{array} \\
F_{c} \\
\left(\mathrm{~N} / \mathrm{mm}^{2}\right)\end{array}$} & \multirow{2}{*}{$\begin{array}{c}\begin{array}{c}\text { Shear } \\
\text { joint } \\
\text { spring }\end{array} \\
\begin{array}{c}K_{s} \\
(\mathrm{kN} / \mathrm{mm})\end{array}\end{array}$} \\
\hline & $\begin{array}{c}\text { Beam } \\
\sigma_{y} \\
\left(\mathrm{~N} / \mathrm{mm}^{2}\right) \\
\end{array}$ & $\begin{array}{c}\text { Column } \\
\sigma_{y} \\
\left(\mathrm{~N} / \mathrm{mm}^{2}\right) \\
\end{array}$ & & & & & \\
\hline No.1 & \multirow{3}{*}{285} & \multirow{3}{*}{359} & \multirow{3}{*}{5,601} & \multirow{3}{*}{438.0} & \multirow{3}{*}{19.3} & \multirow{3}{*}{25.3} & \multirow{3}{*}{273.3} \\
\hline No.2 & & & & & & & \\
\hline No.3 & & & & & & & \\
\hline No.4 & \multirow{2}{*}{308} & \multirow{4}{*}{356} & \multirow{4}{*}{3,513} & \multirow{4}{*}{974.0} & \multirow{4}{*}{12.1} & \multirow{4}{*}{22.0} & 115.1 \\
\hline No.5 & & & & & & & 133.0 \\
\hline No.6 & 299 & & & & & & 214.4 \\
\hline No.7 & 308 & & & & & & 113.9 \\
\hline
\end{tabular}

ネ要素を設け、CLT の圧縮強度で降伏するバイリニア特性を与えた。 支圧バネは、 $50 \mathrm{~mm}$ の等間隔で全幅に分布させて配置することで支 圧力の分布を把握できるようにした。

また、せん断接合部を模擬した弾性バネを CLT の中央部に設け、 バネ剛性は架構実験で試験体毎に得られたせん断剛性を入力した。

鉄骨の柱、梁、引張材は線材要素とし、弾塑性特性はバイリニア 型とした。引張材の上下端はピン接合としてモデル化した。柱・梁 とも部材耐力に曲げモーメントと軸力の相関関係を考慮した。また、 梁の曲げヒンジは危険断面位置に発生するものとして設定した。

CLT を表現した線材要素のせん断特性を弾性とし、支圧部のバネ を弾塑性としたのは、せん断耐力に左右されず大変形時まで CLT の 支圧部の挙動を解析的に把握するためであり、解析結果から CLT が せん断耐力に達した点をグラフ上で事後的に求めることも可能であ る。なお、解析は Midas iGen2018(ver.875R1)を用いた。

Table4 に解析モデルの諸元を示す。支圧剛性は13)式による計算值 を用いた。また、第 1 シリーズの試験体 No.1〜No.3 の CLT せん断 弾性係数は材料試験結果ではなく架構実験から得られた結果を用い た。その他の材料特性は Table2、Table3.に示す值を用いた。

\section{2 荷重-変形関係と破壊モード}

Fig.12、Fig.13 に試験体 No.2 及び No.5 の層間変形角 1/50rad 時 点におけるモーメント図及び降伏状態図を示す。すべての試験体と も鉄骨梁端部における曲げ降伏が発生している。また、試験体 No.2 では、上部鉄骨梁と左側引張材の接合点で、試験体 No.5 では上下 鉄骨梁が CLT から支圧力を受ける部分において鉄骨梁中間部の曲 げ降伏が発生した。また、CLT 支圧バネの降伏が CLT 縁端部より 分布している様子が分かる。他の試験体の解析結果においてもこれ

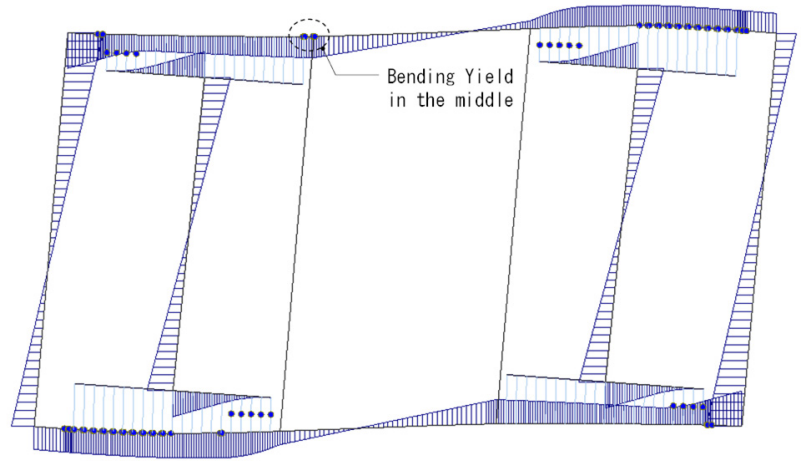

Fig. 12 Diagram of moment and yielding situation of No. 2

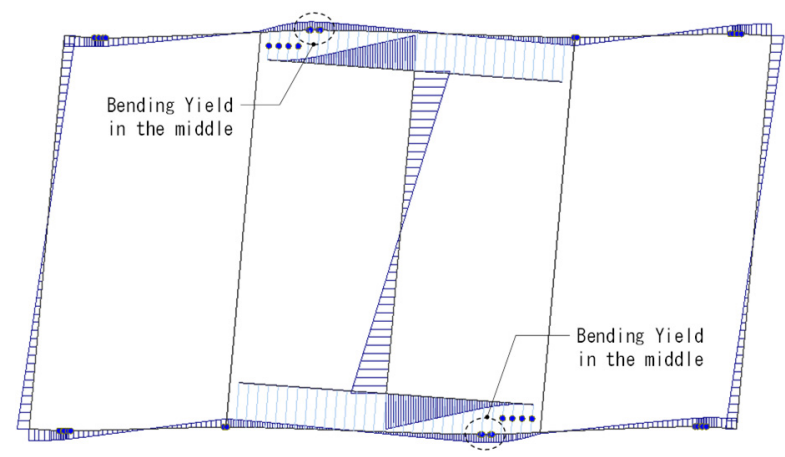

Fig. 13 Diagram of moment and yielding situation of No. 5 

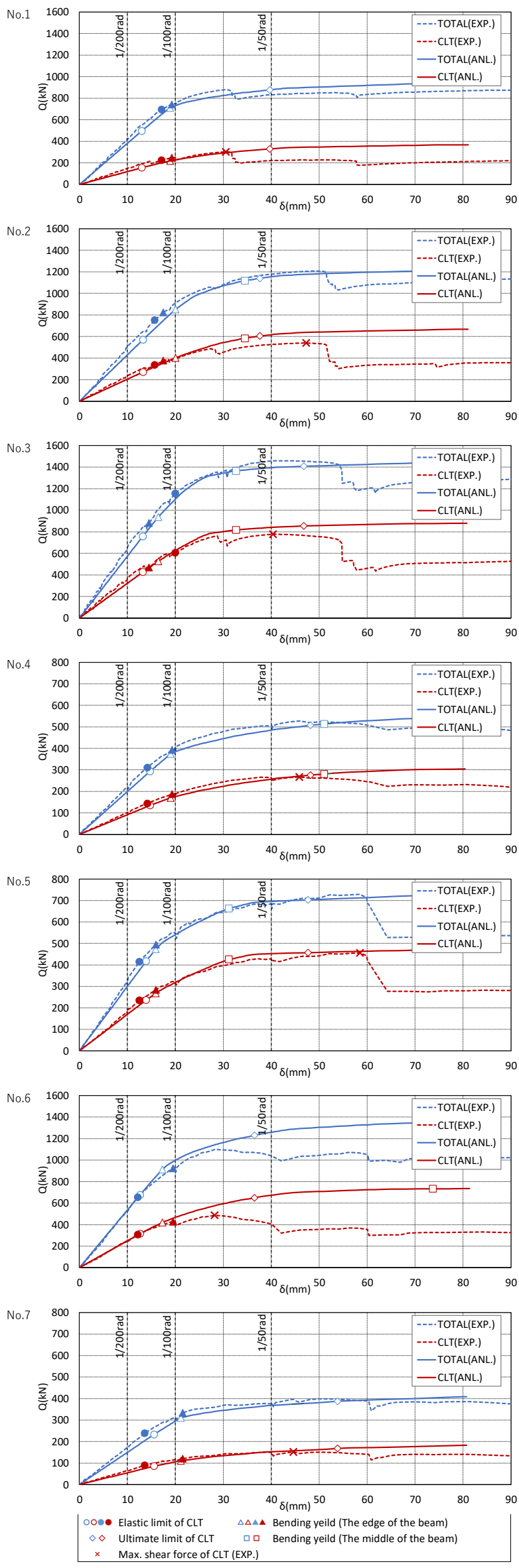

Fig. 14 Comparison of load-story deformation relations between analytical and experimental results
らと同様の降伏状態が発生する。

Fig.14 に荷重 $Q$-層間変形 $\delta$ の関係について解析結果と実験結果を 比較して示寸。なお、実験結果は正加力側の包絡線を示す。図中に は解析結果における特異点として、鉄骨梁端部と中間部の曲げ降伏 の発生点、(14)式による CLT 支圧部の弾性限界時、177式による CLT 縁端部の支圧塑性率が $\mu_{c u}=4.5$ に達した終局支圧時を示す。また。 実験結果については、梁端部の降伏点、2.3 の検討で得られた CLT の弾性限界点（支圧剛性算定点）、CLT の最大耐力時の点を示す。

いずれの試験体も実験結果と解析結果が良く適合した。解析モデ ルでは CLT のせん断耐力を考慮していないが、実験においてせん 断破壊により CLT が耐力低下を生じる層間変形までは実験結果と 良く適合している。

CLT の支圧部の弾性限界点に関してみると、第 2 シリーズの試験 体 No.4 No.7 については良好に再現されている。第 1 シリーズ No.1 No.3 ではやや乘離が見られるが、CLT の荷重変形曲線の形 状そのものは実験結果と解析結果で良く一致しており、弾性限界点 以降徐々に CLT が剛性低下寸る傾向が解析結果においても再現さ れている。

せん断破壊を生じなかった試験体 No.4 と No.7では、実験結果 における CLT 最大耐力とその時の層間変形が解析結果でも同様の 結果が再現された。試験体 No.1、No.5 では解析上の終局支圧時と 実験でのせん断破壊時の耐力が拮抗している。実験結果では最終的 にはせん断破壊を生じても支圧破壊が同時に進行していたことが解 析結果からも推測できる。

以上のように、本解析モデルにより、荷重-層間変形関係や各部の 降伏性状が良好に再現できることが確認できた。

\section{3 支圧バネの挙動}

次に、支圧バネの挙動について確認する。まず、Fig15 に Fig.9 で 示した試験体 No.4 と No. 7 の接合面の鉛直変位分布に解析結果を 重ねたグラフを示す。解析の弾性限界時は(14)式、終局支圧時は(17)式 で $\mu_{c u}=3.0,4.5,6.0$ に達した点を示寸。鉛直変位分布は、弾性限界時 では良く適合し、終局支圧時では支圧領域幅の範囲に注目すると $\mu_{c u}=4.5$ とした場合に良く適合する。3.2の結果も含めて、実験結果 におけるCLT の耐力、変形、及び接合面の鉛直変位分布が、弾性限 界時、終局限界時ともにすべて良好に適合することから、解析モデ ルにおける支圧バネの設定の妥当性が確認できる。また、これらの 結果から支圧バネにおいて $\mu_{c u}=4.5$ となる点を終局支圧時と定義す ることは妥当であると考えられる。

鉛直変位分布の形状に注目寸ると、実験結果で示された 2 点の変 位計による直線分布が示されるのに対して、解析結果では多点の支 圧バネの変位分布が連続的に示されており、その分布形が僅かに曲 線となっていることが確認できる。これは接合面上下の鉄骨梁の変 形に起因するものである。

そこで、その影響を確認するため鉄骨梁の変形を受けやすい試験 体 No.5 と No.6 の解析結果について、接合面の支圧変位、支圧応力 度の分布をFig.16 示す。図中には弾性限界時と層間変形角が 1/67radになった時点とを示す。

まず、両試験体とも CLT 端部の鉛直変位から得られる直線勾配 (図中の点線) と比べて実際の鉛直変位は鉄骨梁の曲率の影響を有 
しており、直線勾配から得られる支圧領域幅よりも実際の支圧領域 幅が小さいことが確認できる。

両試験体とも弾性限界時までは支圧応力度分布はほぼ三角形分布 となるが、その後、支圧バネの塑性化が進み台形分布に移行し、変 形の増大とともに支圧領域幅も漸増する。その際、鉄骨梁剛性の小 さい試験体 No.5 は No,6 よりも、鉛直変位分布形の曲率が大きく、 弾性限界時、層間変形角 $1 / 67 \mathrm{rad}$ 時ともに支圧領域幅が小さくなっ ていることが確認できる。

Table 5 に解析結果における CLT 接合面の鉛直変位分布を直線勾 配とした場合と、実際の変位分布とした場合の支圧領域幅の比較を、 弾性限界時、及び支圧部の塑性化が進んだ $1 / 67 \mathrm{rad}$ 時について示す。 この結果から、実際の支圧領域幅は直線勾配とした場合に対して、 弾性限界時、1/67rad 時とも平均で $79 \%$ 程度になることが分かる。
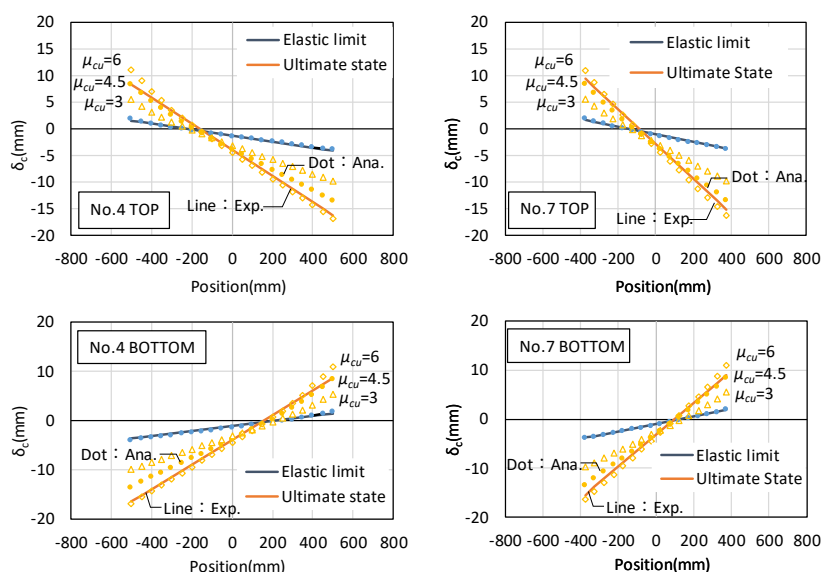

Fig.15 Comparison of experimental and analysis result of distribution of vertical relative displacement
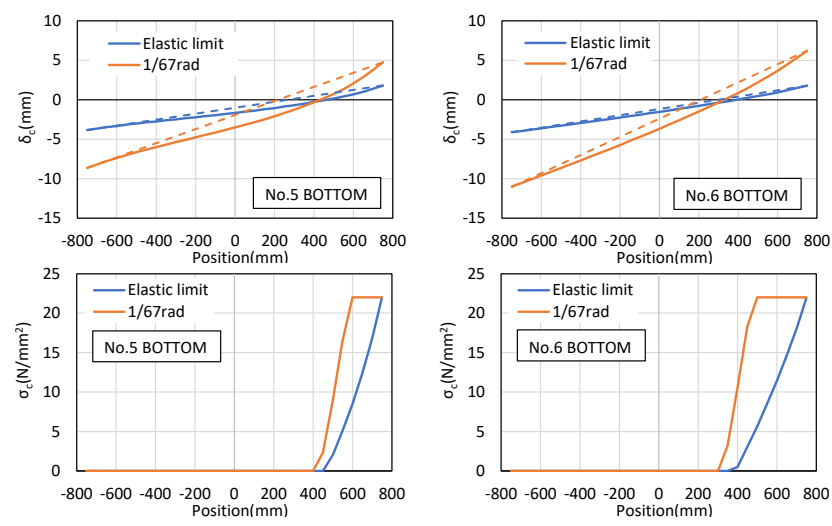

Fig.16 Distribution of vertical relative displacement of the top and bottom connection boundary

Table 5 Real and linear distributions of vertical relative displacements in analysis results

\begin{tabular}{|c|r|r|r|r|r|r|}
\hline \multirow{2}{*}{ No. } & \multicolumn{2}{|c|}{$\begin{array}{c}\text { Real distribution } \\
(\mathrm{mm})\end{array}$} & \multicolumn{2}{c|}{$\begin{array}{r}\text { Linear distribution } \\
(\mathrm{mm})\end{array}$} & \multicolumn{2}{c|}{ Real/Liniear } \\
\cline { 2 - 8 } & Elastic limit & \multicolumn{1}{c|}{$1 / 67$} & Elastic limit & \multicolumn{1}{c|}{$1 / 67$} & Elastic limit & $1 / 67$ \\
\hline No.1 & 243.2 & 283.5 & 283.1 & 327.2 & 0.859 & 0.867 \\
\hline No.2 & 264.7 & 284.3 & 294.7 & 327.1 & 0.898 & 0.869 \\
\hline No.3 & 244.7 & 259.2 & 349.7 & 362.4 & 0.700 & 0.715 \\
\hline No.4 & 245.0 & 270.5 & 316.5 & 345.8 & 0.774 & 0.782 \\
\hline No.5 & 287.0 & 318.9 & 484.7 & 533.3 & 0.592 & 0.598 \\
\hline No.6 & 384.0 & 448.4 & 462.2 & 535.4 & 0.831 & 0.837 \\
\hline No.7 & 205.2 & 223.8 & 235.9 & 256.1 & 0.870 & 0.874 \\
\hline
\end{tabular}

実験結果の支圧領域幅、支圧剛性を評価する際、10式において支圧 領域幅の低減係数を $\lambda=0.8$ と設定したのは、この解析結果を事前に 踏まえたものである。

\section{4. 支圧領域幅と鉄骨梁の変形曲率との関係について}

3.では CLT 支圧部の挙動を検証し、支圧領域幅が鉄骨梁の変形の 影響を受けることを示したが、更にここではその影響をパラメトリ ックな解析的検討により定量化することを試みる。

\section{1 有効支圧領域幅の定義}

これまで示したように、支圧領域幅が縮小寸るのは、CLTからの 支圧力を受けた鉄骨梁の変形による曲率の影響を受けるためと考え られる。また、3.3 で示したように、CLT の寸法や剛性が同じでも 鉄骨梁の剛性が小さいほど曲率が大きくなる。

そこで、鉄骨梁の曲率の生じにくさを示す剛性指標 $K_{\phi}$ を下式のよ うに定義する。

$$
K_{\phi}=\frac{E_{s} \cdot I_{s}}{L_{s}} \quad \cdots(18)
$$

ただし、

$E_{S} ， I_{S} \quad$ : 鉄骨梁のヤング係数、及び断面 2 次モーメント

$L_{s} \quad$ : 鉄骨梁の柱心間スパン

一方、 $K_{\phi}$ との関係を評価するものとして、CLT の回転剛性 $K_{R}$ を 定義する。 $K_{R}$ は、(1)式を用いると下式のようになる。

$$
\begin{aligned}
K_{R} & =\frac{C\left(L-\frac{2}{3} x\right)}{\theta_{R}} \\
& =\frac{1}{2} k_{c} \cdot t \cdot x^{2}\left(L-\frac{2}{3} x\right) \quad \ldots \text { (19) }
\end{aligned}
$$

以上より、支圧領域幅の低減係数 $\lambda_{c} を K_{R}$ と $K_{\phi}$ の比による関数とし て下式のように表現する。

$$
\lambda_{c}=f\left(\frac{K_{R}}{K_{\phi}}\right) \quad \cdots \text { (20) }
$$

これと(4)式より、有効支圧領域幅 $x_{c}$ は、以下のようになる。

$$
x_{c}=\lambda_{c} \cdot x \quad \cdots \text { (21) }
$$

以上の前提で、(4)〜 (6)式で算定される CLT 上下を剛体とした場 合の支圧領域幅 $x$ に対して、鉄骨梁の剛性を考慮した解析結果にお ける支圧領域幅 $x_{c}$ がどのように低減されるかを検討する。

\section{2 解析的検討におけるパラメータ設定}

解析的検討による検討結果をより一般化したものとするため、実 験試験体に加え、より幅広いパラメータを設定した。Table6 に解析 モデルのパラメータ一覧を、Table7 に実施した全 105 ケースの解 析モデルの一覧を示す。

\section{- CLT の材料定数}

まず、CLT 材料定数については、強度等級 S60-5-5 の值として第 1 シリーズ、第 2 シリーズの平均值を基準とした。また、強度等級 S30-5-5、及び S120-5-5 に相当するものとして、強軸方向の圧縮ヤ ング係数を 0.5 倍、及び 2 倍で設定した。圧縮強度は文献 5)に示さ れた各強度等級の基準強度の比率から、S30-5-5は7.02/ $9.72=0.722$ 倍、S120-5-5 は $15.12 / 9.72=1.556$ 倍とした。なお、 支圧剛性 $k_{c}$ は、S60-5-5 に対して文献 5)に示された $k_{c}=15.6 \mathrm{~N} / \mathrm{mm}^{3}$ 
を基準にし、S30-5-5 と S120-5-5 に対してはヤング係数に比例させ た值としたが、結果的に(13)式の算定結果とほぼ同等の值となる。

- CLT の寸法

CLT の幅は試験体と同様に $L=750 \mathrm{~mm} 、 1,000 \mathrm{~mm} 、 1,500 \mathrm{~mm}$ の 3 水準とし、CLT の高さは鉄骨架構の高さに応じ、 $H=1,100 \mathrm{~mm}$ 、

$1,600 \mathrm{~mm} 、 2,600 \mathrm{~mm}$ の 3 水準とした。

・鉄骨架構の寸法

鉄骨架構のスパンは $L_{s}=1,200 \mathrm{~mm} 、 1,800 \mathrm{~mm} 、 3,600 \mathrm{~mm}$ 、 $7,200 \mathrm{~mm}$ の 3 水準とし、高さは $H_{s}=1500 \mathrm{~mm} 、 2000 \mathrm{~mm}$ 、 $3000 \mathrm{~mm}$ の 3 水準とした。これらは実大に換算すると、スパン $2,400 \sim 14,400 \mathrm{~mm}$ 、階高 $3,000 \sim 6,000 \mathrm{~mm}$ に相当し、小規模から 大規模な建築の一般的な寸法をカバーしていることになる。

\section{・鉄骨梁断面}

鉄骨梁断面は、H- $125 \times 125 \times 6.5 \times 9 、 H-194 \times 150 \times 6 \times 9 、 H^{-}$ $294 \times 150 \times 6 \times 9$ の 3 水準としていずれも鋼材種別は SN400 と

し、降伏点強度は $300 \mathrm{~N} / \mathrm{mm}^{2}$ で共通とした。いずれも柱に対し

て、梁の曲げ降伏が先行する断面となっている。

上記のパラメータ設定により、実際の建築物で想定される使用状 況は概ね網羅している。CLT は全て中央配置とし、上記パラメー タ以外の設定は全て試験体モデルと共通とした。なお、引張材の引 張降伏が影響しないように、引張材は弾性を仮定した。

\section{3 パラメトリックスタディの結果}

Fig.17に弾性限界時、終局支圧時の $K_{R} / K_{\phi}$ と $\lambda_{c}$ との関係を示す。

Table 6 Parameters used in analysis study

\begin{tabular}{|c|c|c|c|c|c|c|c|c|}
\hline \multicolumn{3}{|c|}{ Steel Frame } & \multicolumn{6}{|c|}{ CLT } \\
\hline \multirow{2}{*}{$\begin{array}{l}\text { Beam } \\
\text { Section }\end{array}$} & Width & Height & \multirow{2}{*}{$\begin{array}{l}\text { Strength } \\
\text { Grade }\end{array}$} & $\begin{array}{l}\text { Young's } \\
\text { modulus }\end{array}$ & $\begin{array}{c}\text { Compression } \\
\text { strength }\end{array}$ & $\begin{array}{c}\text { Compression } \\
\text { sttifness }\end{array}$ & Width & Hight \\
\hline & $\begin{array}{c}W \\
(\mathrm{~mm})\end{array}$ & $\begin{array}{c}\begin{array}{c}H s \\
(\mathrm{~mm})\end{array} \\
\end{array}$ & & $\begin{array}{c}E_{c} \\
\left(\mathrm{~N} / \mathrm{mm}^{2}\right)\end{array}$ & $\begin{array}{c}F_{c} \\
\left(\mathrm{~N} / \mathrm{mm}^{2}\right)\end{array}$ & $\begin{array}{c}k_{c} \\
\left(\mathrm{~N} / \mathrm{mm}^{3}\right)\end{array}$ & $\begin{array}{c}L \\
(\mathrm{~mm})\end{array}$ & $\begin{array}{c}H \\
(\mathrm{~mm})\end{array}$ \\
\hline \multirow{5}{*}{$\begin{array}{c}{[D 12]} \\
H-125 \times 125 \times 6.5 \times 9 \\
{[D 19]} \\
H-194 \times 150 \times 6 \times 9 \\
{[D 29]} \\
H-294 \times 200 \times 8 \times 12\end{array}$} & $\begin{array}{c}\text { [W12] } \\
1,200\end{array}$ & [H15] & S30-5-5 & 2,279 & 17.1 & 7.8 & \multirow{5}{*}{$\begin{array}{c}{[\mathrm{L} 75]} \\
750 \\
{[\mathrm{~L} 100]} \\
1,000 \\
{[\mathrm{~L} 150]} \\
1,500\end{array}$} & \multirow{5}{*}{$\begin{array}{c}1100 \\
1,600 \\
(1,550) \\
(1,650) \\
2,600\end{array}$} \\
\hline & [W18] & 1,500 & S60-5-5 & 4,557 & 23.7 & 15.6 & & \\
\hline & $\begin{array}{l}1,800 \\
{[\text { W36] }}\end{array}$ & $\begin{array}{l}{[\mathrm{H} 20]} \\
2,000\end{array}$ & s120-5-5 & 9,114 & 36.8 & 31.2 & & \\
\hline & 3,600 & [H30] & No.1 & 5,601 & 25.3 & 19.3 & & \\
\hline & 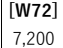 & 3,000 & No4 7 & 3,513 & 22.0 & 12.1 & & \\
\hline
\end{tabular}

弾性限界時、終局支圧時ともに、 $K_{R} / K_{\phi}$ が大きくなるほど $\lambda_{c}$ が減少す る傾向となり、その減少勾配は徐々に緩やかになる。弾性限界時、 終局時とも複数のパラメータを設定したにも関わらずばらつきが少 なく、(20式による評価が有意であると言える。

$\lambda_{c}$ は弾性限界時では $0.2 \sim 0.9$ 、終局時では $0.2 \sim 1.15$ と広範囲で 変動する。このことは、 $K_{R} / K_{\phi}$ が大きい場合、つまり CLT の回転剛 性が大きく鉄骨梁の剛性が低い場合は、実施した実験結果だけから 推測される支圧領域幅よりも大幅に小さくなることを示しており、 CLT 支圧部の耐力評価においては考慮が必要である。

そこで、上記の傾向を数式表現するために、累乗近似を用いた。 ただし、累乗近似の場合、減少傾向を示すには指数が負となり、 $x=$ 0 の時、 $y=\infty$ となるため $x$ の值が小さい場合は著しく精度を欠く。 そこで22式に示寸様に、 $x$ に正の值 $B$ を加えた表現に改めた上で、B の值を連続的に变動させながら最小二乗法により順次近似曲線を求 め、決定係数 ( $R^{2}$ 值) が最も大きくなるような $A, B, C$ の組み合わせを 調べる方法を用いた。

$$
y=A(x+B)^{C} \quad \cdots(22)
$$

この検討方法による結果、下式が得られた。 ・弾性限界時

$$
\lambda_{c e}=3.77\left(\frac{K_{R}}{K_{\phi}}+65.6\right)^{-0.36} \quad \cdots \text { (23) }
$$
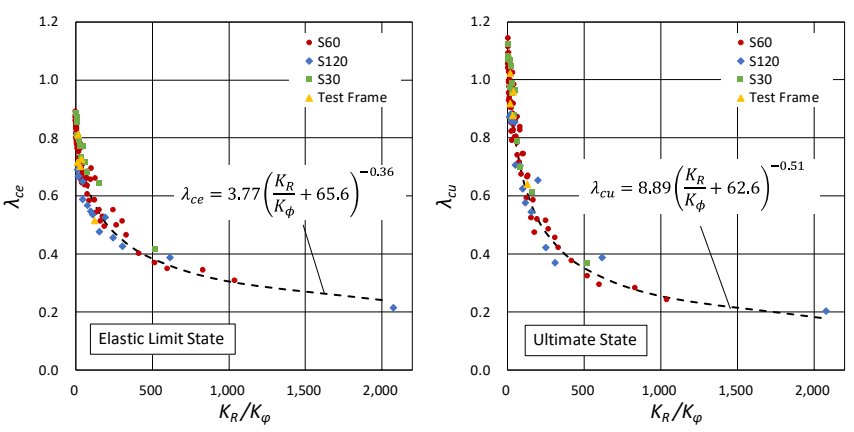

Fig. 17 Relations between stiffness ratios $\left(K_{R} / K_{\phi}\right)$ and compression area width reduction coefficients $\left(\lambda_{c}\right)$

\begin{tabular}{|c|c|c|c|c|c|c|c|c|c|c|c|c|c|c|c|c|c|c|c|c|c|c|c|c|}
\hline$D$ & $H s$ & W & L & $E c$ & $D$ & $H_{s}$ & $w$ & $L$ & $E c$ & $D$ & Hs & $w$ & $L$ & $E C$ & $D$ & Hs & $w$ & $L$ & $E c$ & $D$ & Hs & $w$ & $L$ & $E c$ \\
\hline D12 & H15 & W12 & L75 & S60 & D19 & H15 & W12 & L75 & 560 & D29 & H15 & W12 & L75 & $S 60$ & D12 & $\mathrm{H} 2 \mathrm{O}$ & W18 & L100 & $\mathrm{S} 120$ & D29 & $\mathrm{H} 2 \mathrm{O}$ & W18 & L100 & S30 \\
\hline D12 & $\mathrm{H} 15$ & W18 & L75 & S60 & D19 & H15 & W18 & L75 & $S 60$ & D29 & $\mathrm{H} 15$ & W18 & L75 & S60 & D12 & $\mathrm{H} 2 \mathrm{O}$ & W36 & L100 & $\mathrm{S} 120$ & D29 & $\mathrm{H} 20$ & W36 & L100 & $\mathrm{S} 30$ \\
\hline D12 & $\mathrm{H} 15$ & W18 & L100 & 560 & D19 & H15 & W18 & $\begin{array}{ll}\text { L100 } \\
\end{array}$ & 560 & D29 & $\mathrm{H} 15$ & W18 & L100 & 560 & D12 & $\mathrm{H} 2 \mathrm{O}$ & W72 & $\begin{array}{ll}\text { L100 } \\
\end{array}$ & $\mathbf{S 1 2 0}$ & D29 & $\mathrm{H} 20$ & W72 & $\begin{array}{ll}\text { L100 } \\
\end{array}$ & S30 \\
\hline D12 & $\mathrm{H} 15$ & W36 & L75 & $\mathrm{S} 60$ & D19 & $\mathrm{H} 15$ & W36 & L75 & S60 & D29 & H15 & W36 & L75 & S60 & D12 & $\mathrm{H} 2 \mathrm{O}$ & W72 & L150 & S120 & D29 & $\mathrm{H} 30$ & W36 & L100 & S30 \\
\hline D12 & $\mathrm{H} 15$ & W36 & L100 & $\mathrm{S} 60$ & D19 & $\mathrm{H} 15$ & W36 & L100 & $\mathrm{S} 60$ & D29 & H15 & W36 & L100 & $\mathrm{S} 60$ & D12 & $\mathrm{H} 30$ & W36 & L100 & $\mathrm{S} 120$ & & & th Fram & & \\
\hline D12 & $\mathrm{H} 15$ & W36 & $\begin{array}{l}\text { L150 } \\
\end{array}$ & S60 & D19 & H15 & W36 & $\begin{array}{l}\text { L150 } \\
\end{array}$ & S60 & D29 & H15 & W36 & L150 & S60 & D19 & H15 & W36 & L100 & $\mathrm{S} 120$ & $D$ & $H s$ & $w$ & $L$ & $E C$ \\
\hline D12 & $\mathrm{H} 20$ & W12 & $\begin{array}{l}\text { L75 } \\
\end{array}$ & 560 & D19 & $\mathrm{H} 20$ & W12 & $\begin{array}{l}\text { L75 } \\
\end{array}$ & 560 & D29 & $\mathrm{H} 2 \mathrm{O}$ & W12 & L75 & 560 & D19 & $\mathrm{H} 2 \mathrm{O}$ & W18 & $\begin{array}{ll}\text { L100 } \\
\end{array}$ & $\mathbf{S 1 2 0}$ & D29 & $\mathrm{H} 20$ & W36 & L100 & No.1 \\
\hline D12 & $\mathrm{H} 20$ & W18 & L75 & $\mathrm{S} 60$ & D19 & $\mathrm{H} 20$ & W18 & $\begin{array}{ll}\text { L75 } \\
\end{array}$ & 560 & D29 & $\mathrm{H} 2 \mathrm{O}$ & W18 & L75 & 560 & D19 & $\mathrm{H} 20$ & W36 & L100 & $\mathrm{S} 120$ & D19 & $\mathrm{H} 20$ & W36 & L100 & No.4 \\
\hline $\mathrm{D} 12$ & $\mathrm{H} 20$ & W18 & L100 & 560 & D19 & $\mathrm{H} 20$ & W18 & $\angle 100$ & 560 & D29 & $\mathrm{H} 2 \mathrm{O}$ & W18 & L100 & 560 & D19 & $\mathrm{H} 2 \mathrm{O}$ & W72 & L100 & $\mathrm{S} 120$ & D19 & $\mathrm{H} 20$ & W36 & L150 & No.5 \\
\hline D12 & $\mathrm{H} 2 \mathrm{O}$ & W36 & L75 & S60 & D19 & $\mathrm{H} 20$ & W36 & $L 75$ & S60 & D29 & $\mathrm{H} 2 \mathrm{O}$ & W36 & L75 & 560 & D19 & $\mathrm{H} 30$ & W36 & $\begin{array}{ll}\text { L100 } \\
\end{array}$ & $\mathbf{S 1 2 0}$ & D29 & $\mathrm{H} 20$ & W36 & $\begin{array}{ll}\text { L150 } \\
\end{array}$ & No.6 \\
\hline $\mathrm{D} 12$ & $\mathrm{H} 20$ & W36 & $\begin{array}{l}\text { L100 } \\
\end{array}$ & S60 & D19 & $\mathrm{H} 20$ & W36 & $\begin{array}{ll}\text { L100 } \\
\end{array}$ & S60 & D29 & $\mathrm{H} 2 \mathrm{O}$ & W36 & L100 & S60 & D29 & $\mathrm{H} 20$ & W18 & L100 & S120 & D19 & $\mathrm{H} 2 \mathrm{O}$ & W36 & L75 & No.7 \\
\hline D12 & $\mathrm{H} 20$ & W36 & $\begin{array}{ll}\text { L150 } \\
\end{array}$ & S60 & D19 & $\mathrm{H} 20$ & W36 & $\begin{array}{ll}\text { L150 } \\
\end{array}$ & S60 & D29 & $\mathrm{H} 2 \mathrm{O}$ & W36 & L150 & 560 & D29 & $\mathrm{H} 2 \mathrm{O}$ & W36 & $\begin{array}{ll}\text { L100 } \\
\end{array}$ & $\mathrm{S} 120$ & \multirow{13}{*}{\multicolumn{5}{|c|}{$\begin{array}{l}\text { Parameter symbols of "D, } H s, W, L, E C \text { " } \\
\text { denote the specifications in the table } \\
\text { above. }\end{array}$}} \\
\hline $\mathrm{D} 12$ & $\mathrm{H} 20$ & W72 & $\angle 75$ & $S 60$ & D19 & $\mathrm{H} 20$ & W72 & $\angle 75$ & 560 & D29 & $\mathrm{H} 20$ & W72 & L75 & 560 & D29 & $\mathrm{H} 2 \mathrm{O}$ & W72 & L100 & $\mathrm{S} 120$ & & & & & \\
\hline D12 & $\mathrm{H} 20$ & W72 & L100 & S60 & D19 & $\mathrm{H} 20$ & W72 & L100 & S60 & D29 & $\mathrm{H} 20$ & W72 & L100 & 560 & D29 & $\mathrm{H} 30$ & W36 & $\begin{array}{ll}\text { L100 } \\
\end{array}$ & $\mathbf{S 1 2 0}$ & & & & & \\
\hline D12 & $\mathrm{H} 2 \mathrm{O}$ & W72 & L150 & S60 & D19 & $\mathrm{H} 2 \mathrm{O}$ & W72 & $\begin{array}{l}\text { L150 } \\
\end{array}$ & $S 60$ & D29 & $\mathrm{H} 2 \mathrm{O}$ & W72 & L150 & 560 & 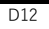 & H2O & W18 & 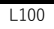 & S30 & & & & & \\
\hline D12 & $\mathrm{H} 30$ & W12 & L75 & S60 & D19 & $\mathrm{H} 30$ & W12 & L75 & S60 & D29 & $\mathrm{H} 30$ & W12 & L75 & 560 & D12 & $\mathrm{H} 2 \mathrm{O}$ & W36 & L100 & $\mathrm{S} 30$ & & & & & \\
\hline D12 & $\mathrm{H} 30$ & W18 & L75 & $\mathrm{S} 60$ & D19 & $\mathrm{H} 30$ & W18 & L75 & $\mathrm{S} 60$ & D29 & $\mathrm{H} 30$ & W18 & L75 & $\mathrm{S} 60$ & D12 & $\mathrm{H} 2 \mathrm{O}$ & W72 & L100 & S30 & & & & & \\
\hline $\mathrm{D} 12$ & $\mathrm{H} 30$ & W18 & L100 & $\mathrm{S} 60$ & D19 & $\mathrm{H} 30$ & W18 & L100 & $\mathrm{S} 60$ & D29 & $\mathrm{H} 30$ & W18 & L100 & 560 & D12 & $\mathrm{H} 2 \mathrm{O}$ & W72 & $\begin{array}{l}\text { L150 } \\
\end{array}$ & $\mathrm{S} 30$ & & & & & \\
\hline D12 & $\mathrm{H} 30$ & W36 & L75 & $\mathrm{S} 60$ & D19 & $\mathrm{H} 30$ & W36 & $L 75$ & $\mathrm{~S} 60$ & D29 & $\mathrm{H} 30$ & W36 & L75 & $\mathrm{S} 60$ & D12 & H30 & W36 & L100 & $\mathrm{S} 30$ & & & & & \\
\hline D12 & $\mathrm{H} 30$ & W36 & L100 & 560 & D19 & $\mathrm{H} 30$ & W36 & L100 & 560 & D29 & $\mathrm{H} 30$ & W36 & L100 & 560 & D19 & $\mathrm{H} 15$ & W36 & L100 & $\mathrm{S} 30$ & & & & & \\
\hline $\mathrm{D} 12$ & $\mathrm{H} 30$ & W36 & L150 & 560 & D19 & $\mathrm{H} 30$ & W36 & L150 & 560 & D29 & $\mathrm{H} 30$ & W36 & L150 & $\mathrm{S} 60$ & D19 & $\mathrm{H} 2 \mathrm{O}$ & W18 & L100 & $\mathrm{S} 30$ & & & & & \\
\hline D12 & $\mathrm{H} 30$ & W72 & L75 & $\mathrm{S} 60$ & D19 & $\mathrm{H} 30$ & W72 & L75 & $\mathrm{S} 60$ & D29 & $\mathrm{H} 30$ & W72 & L75 & $\mathrm{S} 60$ & D19 & $\mathrm{H} 20$ & W36 & L100 & $\mathrm{S} 30$ & & & & & \\
\hline D12 & H3O & W72 & L100 & $\mathrm{S} 60$ & D19 & H3O & W72 & L100 & $\mathrm{S} 60$ & D29 & $\mathrm{H} 30$ & W72 & L100 & $\mathrm{S} 60$ & D19 & $\mathrm{H} 20$ & W72 & L100 & S30 & & & & & \\
\hline D12 & $\mathrm{H} 30$ & W72 & $\begin{array}{ll}L 150 \\
\end{array}$ & S60 & D19 & $\mathrm{H} 30$ & W72 & L150 & S60 & D29 & $\mathrm{H} 30$ & W72 & L150 & S60 & D19 & $\mathrm{H} 30$ & W36 & L100 & S30 & & & & & \\
\hline
\end{tabular}

Table 7 List of parametric analysis models 
・終局支圧時

$$
\lambda_{c u}=8.89\left(\frac{K_{R}}{K_{\phi}}+62.6\right)^{-0.51} \quad \cdots \text { (24) }
$$

Fig.17 に上記の近似曲線を重ねて示した。 $R^{2}$ 值は弾性限界時で 0.935、終局支圧時で 0.959 となり、解析結果の傾向を精度よく評価 できている。また、 $K_{R} / K_{\phi}=0$ のとき、弾性限界時では $\lambda_{c e}=0.84$ 、 $\lambda_{c u}=1.08$ となり上限值も解析結果とよく整合している。

また、Fig.18に $\lambda_{c}$ の(23)式、(24)式による計算值と解析結果による值 との比較を示す。弾性限界時、終局支圧時ともばらつきが少なく、 広いパラメータ設定にも関わらず精度よく評価できている。
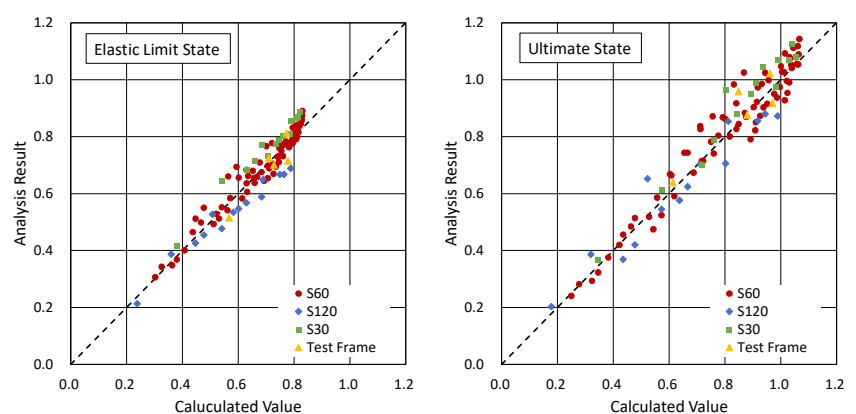

Fig. 18 Comparison of compression area width reduction coefficients $\left(\lambda_{c}\right)$ between calculated and analytical results

\section{5. 支圧耐力式の提案}

これまでの検討結果をもとに、本構造システムにおける CLT 支 圧部の支圧耐力を提案する。

まず、弾性限界時については、支圧応力度の分布が概ね三角形分 布であることから、支圧領域幅低減係数 $\lambda_{c e}$ を考慮して、下式のよう に表現する。

- 弾性限界時の支圧耐力 $C_{e}$ と CLT のせん断力 $Q_{c e}$

$$
\begin{aligned}
C_{e} & =\frac{1}{2} \sigma_{c} \cdot t \cdot x_{c e} \\
Q_{c e} & =\frac{C_{e} \cdot L_{c e}}{H}
\end{aligned}
$$

但し、

$$
\begin{array}{r}
x_{c e}=\lambda_{c e} \cdot x \\
L_{c e}=L-\frac{2}{3} x_{c e}
\end{array}
$$
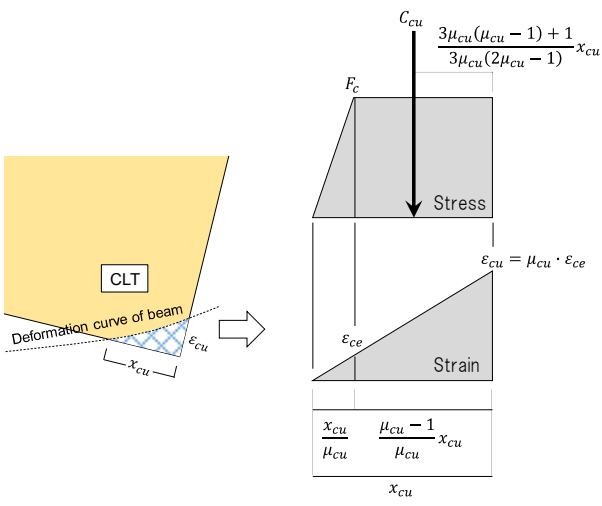

Fig. 19 Model of strain and stress distribution of compression area in the ultimate states
また、終局時は Fig.16 に示寸様に、支圧応力度分布が台形分布に なることから、Fig.19 の様に歪分布、応力度分布をモデル化し、支 圧部縁端部の塑性率 $\mu_{c u}$ を考慮すると、終局時の耐力式が誘導できる。

- 終局時の支圧耐力 $C_{u}$ と CLT のせん断力 $Q_{c u}$

$$
\begin{aligned}
& C_{u}=\frac{2 \mu_{c u}-1}{2 \mu_{c u}} \sigma_{c} \cdot t \cdot x_{c u} \\
& Q_{c u}=C_{u} \frac{L_{c u}}{H} \\
& \text { 但し、 } \\
& x_{c u}=\lambda_{c u} \cdot x \\
& L_{c u}=L-2 \frac{3 \mu_{c u}\left(\mu_{c u}-1\right)+1}{3 \mu_{c u}\left(2 \mu_{c u}-1\right)} x_{c u} \\
& \mu_{c u}=4.5
\end{aligned}
$$

Table 8 と Fig.20 に(26)式と(30式による CLT 支圧部の弾性限界時、 終局時におけるせん断力に対する計算結果と実験值との比較を示す。 弾性限界時、終局時ともに計算結果と実験結果がよく適合している。

\begin{tabular}{|c|c|c|c|c|}
\hline \multirow[b]{2}{*}{ No. } & \multicolumn{2}{|c|}{ Elastic limit } & \multicolumn{2}{|c|}{ Ultimate limit } \\
\hline & $\begin{array}{l}\text { Experimental } \\
\text { result }(\mathrm{kN})\end{array}$ & $\begin{array}{l}\text { Culculation } \\
\text { Value }(k N)\end{array}$ & $\begin{array}{c}\text { Experimental } \\
\text { result }(\mathrm{kN}) \\
(※ \text { Shear failure) }\end{array}$ & $\begin{array}{l}\text { Culculation } \\
\text { Value }(\mathrm{kN})\end{array}$ \\
\hline No.1 & 224.1 & 181.3 & $313.9 \%$ & 343.9 \\
\hline No.2 & 337.0 & 362.6 & $539.4 \%$ & 687.8 \\
\hline No.3 & 605.0 & 543.9 & $802.9 \%$ & 1031.7 \\
\hline No.4 & 144.1 & 141.1 & 267.1 & 265.3 \\
\hline No.5 & 234.7 & 263.4 & $455.6 \%$ & 472.6 \\
\hline No.6 & 306.0 & 348.8 & $487.1 \%$ & 656.5 \\
\hline No.7 & 89.8 & 84.9 & 151.6 & 161.3 \\
\hline
\end{tabular}
弾性限界時の No.3 でやや実験結果が高い值となっているが、2.3 で 述べた支圧剛性の検討において弾性限界時を大きめの変形時に設定 したことによる。また、実験結果でせん断破壊した試験体について は支圧破壊に至らず計算結果の方が高くなっているが、試験体 No.1 と No.5 では支圧破壊とせん断破壊が拮抗していると考えられるた め、実験結果と計算值が良く適合する結果となった。

Table 8 Comparison of shear forces in compressive limit state between calculated and experimental results

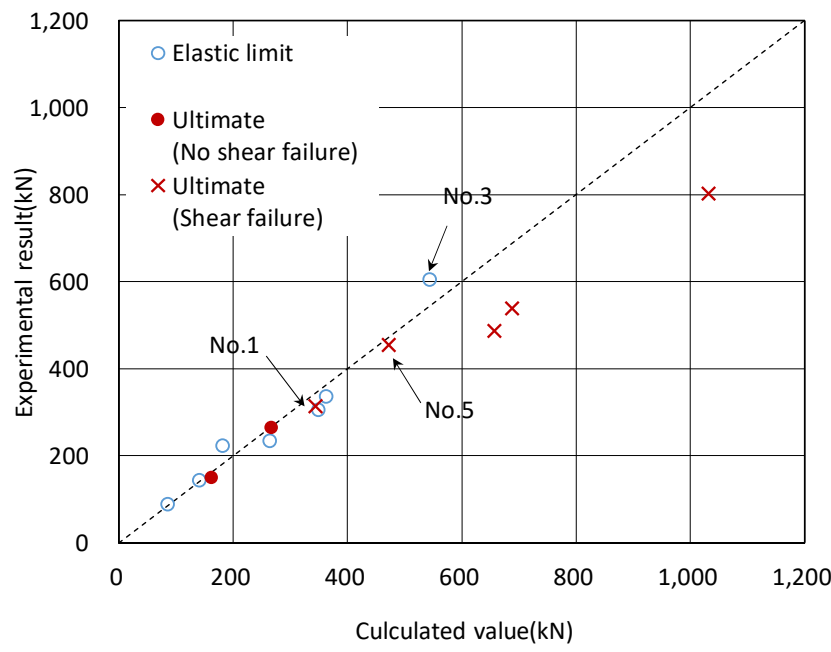

Fig. 20 Comparison of shear forces in compressive limit state between calculated and experimental results 
以上より、提案した支圧耐力式は、支圧部の弾性限界時、終局時 の耐力を評価する上で有用であると考えられる。

\section{6. まとめ}

本報では、CLTを鉄骨造の耐震要素として用いたハイブリッド構 造を対象に、1/2 スケールの実験結果と併せて静的弾塑性解析を用 いた検討を実施し、CLT 隅角部における支圧力の伝達について定量 的に検証した。その結果、以下の知見を得た。

・上下を剛体により拘束された CLT に水平力が作用した場合の応 力伝達をモデル化し、CLT 支圧部の支圧領域幅と、水平剛性の理 論的な計算方法を誘導した。(1)〜8式)

・ 上記の応力伝達モデルをもとに、実験結果における接合面鉛直変 位分布から支圧領域幅と支圧剛性を求め、支圧領域幅は理論計算 值に対し、弾性限界時で 70\%、終局時で 81\%となり、CLT 幅に対 して、弾性限界時で $24 \%$ 、終局時で $28 \%$ となった。

- CLT 支圧部の支圧剛性は圧縮ヤング係数と比例する傾向にあり、 支圧剛性は圧縮ヤング係数の 1/290 とする剛性計算式を提案した。

・この支圧剛性算定式を用いた静的弾塑性解析を実施したところ、 実験結果と良好に適合した。

・解析結果から支圧バネの変形を詳細に検討したところ、鉄骨梁の 変形により支圧変形の分布に曲率が生じ、直線的な分布と仮定し た場合と比べて、本実験結果の範囲では支圧領域幅が平均で $80 \%$ 程度に縮小寸ることが明らかとなった。

・静的弾塑性解析を用いたパラメトリックスタディにより、鉄骨の 梁剛性と CLT の回転剛性の比率と支圧領域幅との関係を検討し、 理論計算值に対する支圧領域幅の低減係数算定式を導いた。(23)、 (24)式)

- 以上の知見をもとに、CLT 支圧部の弾性限界時、終局時における 耐力式を提案し実験結果と良く適合することを確認した。(25)～(33) 式)

以上のように、CLT と鉄骨梁接合面間における支圧力の伝達につ いて定量的な検討を実施し、その評価方法を提案することができた。 一方で、前述した通り、本論では CLT を軸剛性とせん断剛性を有 する線材とみなし隅角部の支圧状態を付加した仮定を置いたが、板 要素としての挙動をする実態とはやや異なる。CLT パネルに圧縮ス トラットが発生することでせん断抵抗が発揮されたときの CLT 面 内の応力度の状態やメカニズムについては不明点が多く、圧縮ス卜 ラットに対する CLT の任意方向のヤング係数も明らかでない。今 後、これらの点を明らかにすることで、より汎用性、普遍性の高い 構造性能評価が可能だと期待している。

\section{参考文献}

1) Bezabeh, M. Tesfamariam, S. and Stiemer, S.: Equivalent viscous damping for steel moment-resisting frames with cross-laminated timber infill walls, Journal of Structural Engineering, ASCE, DOI: 10.1061/(ASCE)ST.1943-541X.0001316. 2015

2) Fukumoto, K., Kouda, M., Saito, M., Okazaki, T., Isoda, H. and Yasui, N. : A Case Study and Future Subjects of Steel Frame Hybrid Structure with CLT Infill Shear Walls, AIJ Journal of Technology and Design, Vol. 26, No.64, pp.923-928, 2020.10 (in Japanese) 福本晃治, 國府田まりな, 齋藤真美, 岡崎智仁, 五十田博, 安井昇 : CLT 而
震パネルを組み込んだ鉄骨ハイブリッド構造の設計事例と抽出された課題, 日本建築学会技術報告集，第 26 巻，第 64 号, pp.923-928，2020.10

3) Namba, T., Kubo K., Tamori, S., Isoda H., Fukumoto K., Kouda M. and Usami T. : Study on Seismic Performance of CLT and Steel Frame Hybrid Structure (Part1, Part2), Summaries of Technical Papers of Annual Meeting, Architectural Institute of Japan, Structure III, pp.645-648, 2019.7 (in Japanese)

難波嵩之, 久保和民, 五十田博, 田守伸一郎, 福本晃治, 國府田まりな, 宇 佐美徹 : CLT+鉄骨ハイブリッド構造システムに関する研究 (その 1 ,その 2 ），日本建築学会大会学術講演梗概集，構造III, pp.645 648, 2019.7

4) Kubo K., Usuta, Y., Fukumoto K., Usami T., Miyauchi, Y., Kitamori, A., Y. and Isoda H. : Study on Seismic Performance of CLT and Steel Frame Hybrid Structure (Part3, Part4, part5), Summaries of Technical Papers of Annual Meeting, Architectural Institute of Japan, Structure III, pp.357-362, 2020.7 (in Japanese) 久保和民，臼田雄作，福本晃治，宇佐美徹，宮内靖昌，北守顕久，五十田 博: CLT+鉄骨ハイブリッド構造システムに関する研究 (その 3 , その 4 , そ の 5 ），日本建築学会大会学術講演梗概集，構造III, pp.357～362，2020.7

5) Japan Housing and Wood Technology Center : Design and construction manual of building using CLT, 2016. 10 (in Japanese) $\mathrm{CLT}$ 設計施工マニュアル編集員会 : 2016 年版 CLT を用いた建築物の設計 施工マニュアル，(公財）日本住宅・木材技術センター, 2016.10

6) Miura A. Isoda H. Tsuchimoto T. Nakagawa T. Kitamori A. Suzuki. K. Tsuda C. : Lateral Structural Performance of Narrow Size Cross Laminated Timber Connected with Tensile Bolts, Journal of Structural and Construction Engineering (Transactions of AIJ), Vol. 81, No.721. pp.583-593, 2016.3 (in Japanese)

弥浦壮太, 五十田博, 槌本敬太, 中川貴文, 北守顕久, 鈴木圭, 津田千 尋：小幅パネルを引きボルト接合した CLT 壁の水平力に対する挙動, 日本 建築学会構造系論文集, 第 81 巻, 第 721 号, pp.583 593, 2016.3

7) Architectural Institute of Japan : Standard for Structural Design of Timber Structure, MARUZEN CO. 2013.5 (in Japanese) 木質構造設計規準・同解説，(一社）日本建築学会, 2013.5

8) Architectural Institute of Japan: Design Manual of Engineered Timber Joints, MARUZEN CO. 2009.11 (in Japanese) 木質構造接合部設計マニュアル（一社） 日本建築学会, 2009.11 


\author{
Kouji FUKUMOTO ${ }^{* 1}$ and Hiroshi ISODA *2 \\ ${ }^{11}$ Senior Manager, Structural Engineering Section, Design Dept., Takenaka Corporation, M.Eng. \\ (Research Institute for Sustainable Humanosphere, Kyoto Univ.) \\ ${ }^{2}$ Prof., Research Institute for Sustainable Humanosphere, Kyoto Univ., Dr.Eng.
}

This paper shows the quantitative verification of the stress transfer performance of CLT compression areas and shear joints through the studies of the static elastic-plastic analysis and experimental results, and the following results have been achieved.

- By assuming a stress state model of a CLT panel, restrained at the top and bottom by rigid bodies, with a horizontal force applied, the theoretical calculation formulas for the compression area width and horizontal stiffness of CLT have been developed. (Equations No. 1 to No. 8)

- The compression area width found from the distribution of the vertical deformations in the joint areas in the experimental results was $70 \%$ and $81 \%$ of the theoretical calculation results, respectively, in the elastic limit and ultimate states, and $24 \%$ and $28 \%$ for the CLT width.

- Since the compression stiffness of the CLT compression area tends to be proportional to its compressive Young's modulus, the stiffness calculation formula is proposed, where the compression stiffness is generally 1/290 of the Young's modulus. (Equation No. 13)

- The results of the static elastic-plastic analysis performed using the above compression stiffness calculation formula were in good agreement with the experimental results.

- The further study on the deformation of the CLT compression springs of the analysis model revealed that a curvature occurred in the distribution of vertical deformations due to the curvature of the steel beam. Furthermore, it was found that the width of compression area was reduced to on average approximately $80 \%$, compared with the assumed linear distribution.

- The formulas to calculate the coefficient of reduction of the compression area width from the theoretical calculation values were derived from the parametric study using static elastic-plastic analysis on the relations between the ratio of the rotational stiffness of CLT to the curvature stiffness of steel beam and the width of compression area. (Equations No. 23 and No. 24)

- On the basis of the above findings, we have developed the formulas for the compression bearing capacity of CLT in the elastic limit and ultimate states (Equations No. 25 to No. 33), and confirmed that the results calculated using the formulas were in good agreement with the experimental results. 